\title{
Serotonin Uptake Sites and Serotonin Receptors Are Altered in the Limbic System of Schizophrenics
}

Ieffrey N. Joyce, Ph.D., Andi Shane, B.S., Nedra Lexow, M.S., Andrew Winokur, M.D., Ph.D., Manuel F. Casanova, M.D., Ph.D., and Joel E. Kleinman, M.D.

Serotonin (5-HT) uptake sites were mapped by autoradiographic means with $\left[{ }^{3} \mathrm{H}\right]$ cyano-imipramine $\left.\left({ }^{3} \mathrm{H}\right) \mathrm{CN}-\mathrm{IMI}\right)$, the $5-\mathrm{HT}_{1 \mathrm{~A}}$ receptor with $\left[{ }^{3} \mathrm{H}\right] 8$-hydroxy2-[di-n-propyl-amino]tetralin $\left(\left[{ }^{3} \mathrm{H} / 8-\mathrm{OH}-\mathrm{DPAT}\right)\right.$, and the $5-\mathrm{HT}_{2}$ receptor with both $\left[{ }^{3} \mathrm{H} / \mathrm{ketanserin}\right.$ and [25I]lysergic acid diethylamide ([225I]LSD) in eight nonneurologic controls and 10 cases with a diagnosis of schizophrenia. In the striatum, there was a marked heterogeneous patterning of 5-HT uptake sites that corresponded to the striosomal/matrix

compartmentalization of the striatum. This organization was not matched with an equally heterogeneous pattern of either $5-H T_{2}$ or $5-H T_{1 A}$ receptors. For the isocortex, a general organizational scheme was observed with the $5-H T_{1 A}$ receptor expression high in the external laminae and deep laminae, but $5-\mathrm{HT}_{2}$ receptor expression was higher in the internal laminae. There was a laminar distribution of 5-HT uptake sites that approximated the combined distributions of the $5-H T_{1 A}$ receptor and the $\mathrm{SHT}_{2}$ receptor. In the parahippocampal gyrus and hippocampus, the distribution of 5-HT uptake sites was complementary to the distribution of $5-\mathrm{HT}_{1 A}$ and
5- $\mathrm{HT}_{2}$ receptors. In schizophrenic cases, there was a large increase in the number and altered striosomal/matrix organization of 5-HT uptake sites in the striatum. There was also an increase in the numbers of $5-\mathrm{HT}_{2}$ receptors in the nucleus accumbens and ventral putamen of the schizophrenics. The number of 5-HT $T_{1 A}$ receptors was not modified. There was a marked reduction in 5-HT uptake sites in the external and middle laminae of the anterior cingulate, frontal cortex, and posterior cingulate, and no changes were observed in the motor cortex, temporal cortex, or hippocampus. Increased numbers of 5-HT receptors were found in the posterior cingulate, motor cortex, and hippocampus. Serotonin, receptors were substantially elevated in the posterior cingulate, temporal cortex, and hippocampus, but not in the frontal, anterior cingulate, or motor cortices. Examination of the temporal lobe and hippocampus of a group of nonschizophrenic suicides $(\mathrm{n}=8)$ indicated the alterations in $5-H T$ system in the limbic regions of the striatum, the limbic cortex, and hippocampus of the schizophrenic cases may be disease specific. [Neuropsychopharmacology 8:315336, 1993.
From the Departments of Psychiatry and Pharmacology (JNJ, AS, NL, AW), University of Pennsylvania School of Medicine, Philadelphia, Pennsylvania; and Clinical Brain Disorders Branch (MFC, (EX), National Institute of Mental Health, St. Elizabeths Hospital, Washington, DC.

Address correspondence to: Jeffrey N. Joyce, Ph.D., Laboratory of Chemical Neuroanatomy, Department of Psychiatry, University of Pennsylvania School of Medicine, 422 Currie Boulevard, Philadelphia, Pennsylvania 19104-6141.

Received October 9, 1991; revised June 11, 1992 and October 19, 1992; accepted October 26, 1992.
KEY WORDS: Quantitative autoradiography; Serotonin uptake; Serotonin ${ }_{1 A}$ receptor; Serotonin 2 receptor; Striatum; Cortex; Hippocampus; Schizophrenia

Although the role for dopamine (DA) in schizophrenia has received considerable attention, a possible role for serotonin (5-HT) is under investigation (see Bleich et al. 1988; Meltzer 1989). However, the evidence has been largely indirect; investigators have shown that some 
antipsychotics have affinity for both DA and 5-HT receptors (Meltzer et al. 1989), or selective (e.g., risperidone, setoperone, and ritanserin) serotonergic properties (Castelão et al. 1989; Vinar et al. 1989). Direct evidence for changes in the levels of 5-HT or density of 5 -HT receptors in the brains of schizophrenics has been difficult to obtain. Although some groups have reported changes in levels of 5-HT in the cortex of schizophrenic cases, the only replicable finding has shown increased 5-HT and/or 5-hydroxyindoleacetic acid (5-HIAA) in the putamen and globus pallidus (Crow et al. 1979; Farley et al. 1980; Korpi et al. 1986). However, these findings were not supported by the earlier findings of Joseph and associates (1979) and Winblad and associates (1979), who determined that the most affected region was the hippocampus. Some of the variability in the results of these studies may be related to the fact that a significant number of schizophrenics attempt suicide (Roy 1984) and reduced concentrations of forebrain 5-HT content and numbers of the high-affinity 5-HT transport (uptake) sites have been reported in the brains of suicide victims (Crow et al. 1984; Gross-Isseroff et al. 1989; Stanley et al. 1982).

The physiologic actions of 5-HT appear to be mediated by its interaction with three general classes of receptors: $5-\mathrm{HT}_{1}, 5-\mathrm{HT}_{2}$, and $5-\mathrm{HT}_{3}$ (for review see, Frazer et al. 1990). The density of 5- $\mathrm{HT}_{2}$ receptors, labeled with $\left[{ }^{3} \mathrm{H}\right]$ lysergic acid diethylamide $\left(\left[{ }^{3} \mathrm{H}\right] \mathrm{LSD}\right)$ or $\left[{ }^{3} \mathrm{H}\right]$ ketanserin, has been shown to be reduced (Bennett et al. 1979; Mita et al. 1986), unchanged, or increased (Whitaker et al. 1981; Reynolds et al. 1983) in the frontal cortex of schizophrenic cases. Again, variability in results may be caused by the inclusion of individuals whose death occurred by suicide, as there have been reports of increased densities of 5-HT receptors (Stanley and Mann 1983; Mann et al. 1986; Arango et al. 1990; Arora and Meltzer 1989a) and decreased densities (Crow et al. 1984; Gross-Isseroff et al. 1990) for suicide cases. Recently, Hashimoto and associates (1991) reported an increase in $5-\mathrm{HT}_{1 \mathrm{~A}}$ receptors in the frontal and temporal cortex of schizophrenic cases. However, such changes have also been observed in patients committing suicide (Dillon et al. 1991). Consequently, it is unclear to what extent alterations in the 5-HT system in schizophrenic cases is disease specific.

Receptor autoradiography can be a particularly useful tool for exploring the altered expression of transmitter systems in brains of patients with neuropsychiatric disorders (Joyce et al. 1988, 1992). Studies that directly explore the relationship between the distribution of 5-HT uptake sites and 5-HT receptors in human brain by using autoradiographic means have not been published. Moreover, much of the research on the receptor disturbances in schizophrenia predates the development of radioligands selective for subtypes of the 5-HT receptor, and of radioligands that can selectively label the uptake site for 5-HT located on 5-HT terminals. To determine whether alterations in the 5-HT system can occur in schizophrenic cases, the autoradiographic mapping of 5-HT uptake sites, $5-\mathrm{HT}_{1 \mathrm{~A}}$ and $5-\mathrm{HT}_{2}$ receptors sites, was examined in tissue sections obtained from 10 subjects with a diagnosis of schizophre nia and eight cases of nonschizophrenic suicide and compared to those of eight controls. The distribution of high-affinity uptake sites for 5-HT was mapped with the compound $\left[{ }^{3} \mathrm{H}\right]$ cyano-imipramine $\left(\left[{ }^{3} \mathrm{H}\right] \mathrm{CN}-\mathrm{IM}\right)$ (Joyce et al. 1992; Kovachich et al. 1988), the 5- $\mathrm{HT}_{\text {A }}$ receptor of the $5-\mathrm{HT}_{1}$ family with $\left[{ }^{3} \mathrm{H}\right] 8$-hydroxy-2-[di$n$-propyl-amino $]$ tetralin $\left(\left[{ }^{3} \mathrm{H}\right] 8-\mathrm{OH}-D P A T\right)$ (Pazos et al. 1987a), and $5-\mathrm{HT}_{2}$ receptors with both $\left[{ }^{3} \mathrm{H}\right]$ ketanserin (Pazos et al. 1987b) and [125I]LSD (Engel et al. 1984).

\section{MATERIALS AND METHODS}

\section{Human Autopsy Tissue}

Whole brain hemispheres were obtained from the Brain Tissue Resource Center of McLean Hospital, Harvard University, Boston, Massachusetts and from the Neuropathology Section, Clinical Brain Disorders Branch of the National Institute of Mental Health, Bethesda, Maryland. Brain tissues were taken from 10 subjects with a diagnosis of schizophrenia and eight cases of nonschizophrenic suicide (Table 1). In all cases the diagnosis of schizophrenia was confirmed by two independent clinicians using DSM-III-R criteria. Determination of drug consumption was based upon retrospective analysis of case reports and toxicology screening. One schizophrenic case had a prefrontallobotomy and had taken antiseizure medicine. On the basis of interviews with the family or close relatives, the nonschizophrenic suicide cases were identified as not having a history of schizophrenia and a probable history of affective illness. One patient died from suffocation while asleep; high levels of ethanol were subsequently found at autopsy. This patient had a history of manic-depressive illness but was not judged to have committed suicide. The postmortem interval (PMI), determined for all cases as the time between death and initiation of autopsy procedures, varied from 2 to 29 hours.

In all cases where tissue was provided by sources outside the Hospital of the University of Pennsylvania, the tissue was frozen at autopsy and stored at $-80^{\circ} \mathrm{C}$ until processed for autoradiography. Tissue from the two cases with a diagnosis of suicide was obtained from the Medical Examiner's office of the City of Philadelphia (H.M.Mirchandani, Chief Medical Examiner) and the tissue was frozen at autopsy by one of the authors (JNJ). Brain tissue from six age-matched controls was obtained at autopsy (PMI 6 to 24 hours) from the Hos- 
Table 1. Data for Autopsy Cases

\begin{tabular}{|c|c|c|c|c|c|c|c|}
\hline Case No. & Age & Sex & PMI & Cause of Death & Medication History & Hem & Source \\
\hline \multicolumn{8}{|l|}{ Controls } \\
\hline 1 & 66 yrs & $\mathrm{F}$ & $19 \mathrm{hr}$ & cardiac arrest & none $(-)$ & left & HUP \\
\hline 2 & 84 yrs & $\mathbf{M}$ & $24 \mathrm{hr}$ & cardiac arrest & none $(-)$ & right & HUP \\
\hline 3 & 80 yrs & M & $21 \mathrm{hr}$ & respiratory arrest & none $(-)$ & left & HUP \\
\hline 4 & 60 yrs & $\mathrm{F}$ & $18 \mathrm{hr}$ & cardiac arrest & none $(-)$ & left & HUP \\
\hline 5 & 77 yrs & $\mathbf{M}$ & $6 \mathrm{hr}$ & respiratory arrest & ethanol $(+)$ & right & HUP \\
\hline 6 & 82 yrs & $\mathrm{F}$ & $19 \mathrm{hr}$ & cardiac arrest & none $(-)$ & left & HUP \\
\hline 7 & 56 yrs & $\mathbf{M}$ & $24 \mathrm{hr}$ & respiratory arrest & none $(-)$ & Both & ME \\
\hline 8 & 40 yrs & $\mathrm{F}$ & $24 \mathrm{hr}$ & auto accident & none $(-)$ & Both & $\mathrm{ME}$ \\
\hline Means $n=8$ & $68 \pm 15$ & $4 \mathrm{~F}, 4 \mathrm{M}$ & $19 \pm 6$ & & & & \\
\hline \multicolumn{8}{|l|}{ Schizophrenia } \\
\hline 9 & 56 yrs & $\mathbf{M}$ & $28 \mathrm{hr}$ & cardiac arrest & dilantin, chloralhydrate $(+)$ & Both & NIMH \\
\hline 10 & 27 yrs & $\mathbf{M}$ & $8 \mathrm{hr}$ & hanging & proloxin & right & McLean \\
\hline 11 & 59 yrs & M & $24 \mathrm{hr}$ & cardiac arrest & none $(-)$ & left & McLean \\
\hline 12 & 52 yrs & $\mathbf{M}$ & $28 \mathrm{hr}$ & cardiomyopathy & haldol & right & NIMH \\
\hline 13 & 51 yrs & $\mathrm{F}$ & $12 \mathrm{hr}$ & cardiac arrest & thorazine $(+)$, haldol $(-)$ & left & NIMH \\
\hline 14 & 82 yrs & M & $18 \mathrm{hr}$ & cardiac arrest & haldol, valium, dilantin & Both & HUP \\
\hline 15 & 65 yrs & M & $2 \mathrm{hr}$ & psepsis & none $(-)$ & left & McLean \\
\hline 16 & 30 yrs & M & $3 \mathrm{hr}$ & suicide - drowning & none $(-)$ & right & NIMH \\
\hline 17 & 36 yrs & $\mathrm{F}$ & $11 \mathrm{hr}$ & suicide-jumping & none $(-)$ & left & NIMH \\
\hline 18 & 30 yrs & $\mathbf{F}$ & $6 \mathrm{hr}$ & suicide-jumping & trilafin $(-)$ & Both & NIMH \\
\hline Means $n=10$ & $49 \pm 18$ & 7M,3F & $14 \pm 10$ & & & & \\
\hline \multicolumn{8}{|c|}{ Suicide/Affective Illness } \\
\hline 19 & 59 yrs & $\mathrm{F}$ & $25 \mathrm{hr}$ & jumping & imipramine, amytryptilene $(+)$ & right & NIMH \\
\hline $20^{b}$ & 49 yrs & $\mathrm{F}$ & $28 \mathrm{hr}$ & suffocation & ethanol $(+)$ & left & NIMH \\
\hline 21 & $28 \mathrm{yrs}$ & $\mathrm{F}$ & $34 \mathrm{hr}$ & gunshot-abdomen & nomifensine $(+)$ & Both & NIMH \\
\hline 22 & 32 yrs & $\mathbf{M}$ & $18 \mathrm{hr}$ & gunshot - head & imipramine, benadryl $(+)$ & left & NIMH \\
\hline 23 & 40 yrs & $\mathbf{M}$ & $23 \mathrm{hr}$ & gunshot-head & ethanol & right & NIMH \\
\hline 24 & $39 \mathrm{yrs}$ & M & $33 \mathrm{hr}$ & jumping & nardil (+) & right & NIMH \\
\hline 25 & 15 yrs & $\mathbf{M}$ & $29 \mathrm{hr}$ & gunshot-head & none $(-)^{\prime}$ & left & $\mathrm{ME}$ \\
\hline & 43 yrs & $\mathbf{M}$ & $29 \mathrm{hr}$ & gunshot-head & none $(-)$ & right & $\mathrm{ME}$ \\
\hline Means $n=8$ & $38 \pm 13$ & $3 \mathrm{~F}, 5 \mathrm{M}$ & $27 \pm 9$ & & & & \\
\hline
\end{tabular}

In all cases the tissue had been frozen at autopsy and stored at $-80^{\circ} \mathrm{C}$ until processed for autoradiography. Cases were obtained from Hospital of the University of Pennsylvania (HUP), St. Elizabeths Hospital, National Institute of Mental Health (NIMH), McLean Hospital (Mclean) or the Medical Examiner's office, City of Philadelphia (ME) as detailed in Materials and Methods. The mean \pm standard deviation is given for the age and PMI for the control, schizophrenia, and suicide/affective illness groups.

$(+)$ Indicates positive for drugs with toxicology screen.

(-) Indicates negative for drug with toxicology screen.

"Prefrontal lobotomy.

${ }^{b}$ Diagnosis of manic-depressive, suffocation was not a suicide.

pital of the University of Pennsylvania (J. Trojanowski, Director of Medical Pathology), rapidly frozen at $-40^{\circ} \mathrm{C}$, and stored at $-80^{\circ} \mathrm{C}$. Two additional control cases were obtained from the Medical Examiner's office of the City of Philadelphia, rapidly frozen at $-40^{\circ} \mathrm{C}$, and stored at $-80^{\circ} \mathrm{C}$. The control group was composed of individuals who died of natural or accidental causes and had no history of neurologic or psychiatric disease. Gross pathology of the control brains at autopsy appeared normal. There were no significant differences in the mean age or PMI between the controls, schizophrenic cases, or nonschizophrenic suicide cases.

For the control and schizophrenic cases, coronal slabs at three anterior-posterior levels of the brain were sectioned and processed for receptor autoradiography. The anterior section (Fig. 1A) included the head of the caudate, rostral putamen, anterior cingulate (area 24), premotor (area 6), and frontal cortex (area 9, not including frontal pole). The midcoronal level contained the caudate, putamen, globus pallidus, and frontal cortex (Fig. 1B). The posterior level included the precentral cortex (areas 4 and 23), postcentral cortex (areas 1 and 5), temporal cortex (Brodmann's 22, 41, 42 and 20, 21, 37 , not including rostral pole), posterior cingulate, parahippocampus, and hippocampus (Fig. 1C). In all control and schizophrenic cases, the coronal levels were matched for rostral-caudal position. For the suicide cases, coronal levels containing the hippocampus with the temporal and parietal cortex solely were used. For autoradiographic experiments, the brains were sectioned at $20 \mu \mathrm{m}$ in a Lipshaw $1800-\mathrm{N}$ cryotome at $-25^{\circ} \mathrm{C}$, thaw-mounted onto gelatin-subbed slides, 
Figure 1. Schematic diagram showing regions analyzed by each level $(A, B, C)$ and the subfields of the hippocampus (D). Abbreviations: area 6, premotor; area 24 , anterior cingulate; area 9, prefrontal; area 4, motor cortex; area 23, cingulate cortex; areas 1 and 5 , somatosensory; $\mathrm{C}$, caudate nucleus; $\mathrm{CA}_{1-}$ $\mathrm{CA}_{4}$, subfields of the hippocampus; $\mathrm{H}$, parahippocampus and hippocampus; $P$, putamen; $\mathrm{T}$, temporal cortex.

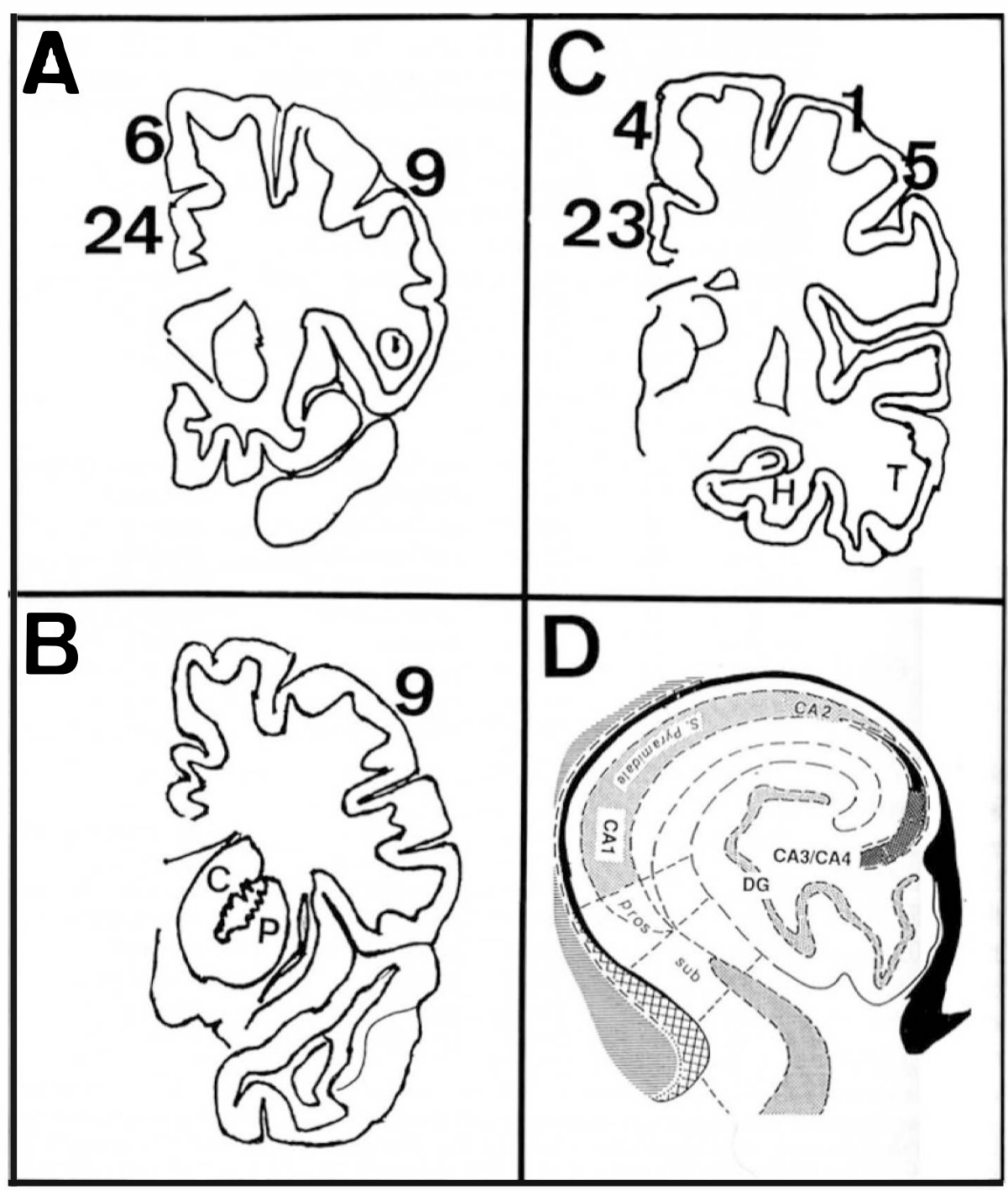

dried at $0^{\circ} \mathrm{C}$ under reduced pressure, and stored at $-80^{\circ} \mathrm{C}$ until further use in the experiments. Every 20th section was retained for Nissl staining.

\section{Radioligand Protocols}

Two radioligands were utilized to label $5-\mathrm{HT}_{2}$ receptors in tissue sections. The protocol for $\left[{ }^{3} \mathrm{H}\right]$ ketanserin labeling of 5- $\mathrm{HT}_{2}$ receptors was adapted from that of Pazos and associates (1987b) and the procedure for [125I]LSD labeling of $5-\mathrm{HT}_{2}$ receptors was modified from that of Engel and associates (1984). Information from the use of both radioligands was utilized to address issues of the specificity for [ $\left.{ }^{125} \mathrm{I}\right] \mathrm{LSD}$ labeling of $5-\mathrm{HT}_{2}$ receptors. Tissue sections were preincubated for 15 minutes at room temperature in the incubation buffer. Sections were incubated with $2 \mathrm{nmol} / \mathrm{L}\left[{ }^{3} \mathrm{H}\right]$ ketanserin $(61 \mathrm{Ci} /$ mmol; DuPont New England Nuclear) in a buffer containing $0.17 \mathrm{~mol} / \mathrm{L}$ Tris, $\mathrm{pH} 7.7$, for 2 hours at room tem- perature. Adjacent sections were incubated similarly but contained $1 \mu \mathrm{mol} / \mathrm{L}$ mianserin for the definition of nonspecific binding. Slide-mounted sections were washed two times for 5 minutes each at $4^{\circ} \mathrm{C}$ and briefly rinsed in $\mathrm{H}_{2} \mathrm{O}$ before drying. Alternating sets of slide mounted tissue sections were incubated with 200 $\mathrm{pmol} / \mathrm{L}$ (or in some regions $200 \mathrm{pmol} / \mathrm{L}, 700 \mathrm{pmol} / \mathrm{L}$, $900 \mathrm{pmol} / \mathrm{L}, 1.1 \mathrm{nmol} / \mathrm{L}$, and $1.9 \mathrm{nmol} / \mathrm{L}$ ) [ $\left.{ }^{125}\right]$ [SD $(2200 \mathrm{Ci} / \mathrm{mmol}$; DuPont New England Nuclear) in a buffer containing $50 \mathrm{mmol} / \mathrm{L}$ Tris pH 7.4, $10 \mu \mathrm{mol} / \mathrm{Lsul}$. piride, $1 \mu \mathrm{mol} / \mathrm{L}$ tripolidine, and $1 \mu \mathrm{mol} / \mathrm{L}$ prazosin. Adjacent sections were incubated similarly but contained $1 \mu \mathrm{mol} / \mathrm{L}$ ketanserin for the definition of nonspecific binding. The results of preliminary experiments done to define optimal incubation procedures, in which the binding of $200 \mathrm{pmol} / \mathrm{L}$ [ $\left.{ }^{125} \mathrm{I}\right] \mathrm{LSD}$ to sections of rat and human brain was determined by liquid scintillation counting, indicated that the binding of $\left[{ }^{125} \mathrm{I}\right] \mathrm{LSD}$ reached equilibrium by 60 minutes at room tempera. 
ture. Consequently, all tissue sections were incubated for 1 hour at $22^{\circ} \mathrm{C}$, washed three times at $4^{\circ} \mathrm{C}$ for 20 minutes each, and dried under a stream of cool air.

To label 5- $\mathrm{HT}_{1 \mathrm{~A}}$ receptors, the procedure of Pazos and associates (1987a) was followed with minor modifcations (Hensler et al. 1991). The slide-mounted tissue sections were preincubated for 30 minutes in the incubation buffer. The sections were incubated with 2 nmol/L [ $\left.{ }^{3} \mathrm{H}\right] 8-\mathrm{OH}-D P A T(158 \mathrm{Ci} / \mathrm{mmol}$; DuPont New England Nuclear) in a buffer containing $4 \mathrm{mmol} / \mathrm{L}$ $\mathrm{CaCl}_{2}, 0.17 \mathrm{~mol} / \mathrm{L}$ Tris- $\mathrm{HCl}$ buffer, $0.01 \%$ ascorbic acid, $\mathrm{pH} 7.6$, and $10 \mu \mathrm{mol} / \mathrm{L}$ pargyline. Adjacent sections were incubated similarly but contained $5 \mu \mathrm{mol} / \mathrm{L} 5-\mathrm{HT}$ for the definition of nonspecific binding. Incubations werecarried out in a light-proof room for 1 hour at $22^{\circ} \mathrm{C}$, washed twice for 5 minutes at $4^{\circ} \mathrm{C}$ in buffer, and washed for 10 seconds in $\mathrm{H}_{2} \mathrm{O}$ at $4^{\circ} \mathrm{C}$.

To visualize the 5-HT uptake sites located on 5-HT terminals, the radioligand $\left[{ }^{3} \mathrm{H}\right] \mathrm{CN}$-IMI was used (Kovachich et al. 1988; Joyce et al. 1992). Slide-mounted tissue sections were preincubated for 10 minutes at $4^{\circ} \mathrm{C}$ inbuffer. The sections were incubated with $0.5 \mathrm{nmol} / \mathrm{L}$ $\left[{ }^{3} \mathrm{H}\right] \mathrm{CN}$-IMI $\left(78.2 \mathrm{Ci} / \mathrm{mmol}, \mathrm{K}_{\mathrm{d}}=0.14 \mathrm{nmol} / \mathrm{L}\right)$ in buffer containing $50 \mathrm{mmol} / \mathrm{L}$ Tris plus $150 \mathrm{mmol} / \mathrm{L}$ $\mathrm{NaCl}, \mathrm{pH}$ 7.4. Adjacent sections were incubated similarly but contained $100 \mu \mathrm{mol} / \mathrm{L}$ desipramine for the definition of nonspecific binding. Incubations were carnied

washed twice for 1 hour at $4^{\circ} \mathrm{C}$ in buffer, and $10 \mathrm{sec}-$ onds in $\mathrm{H}_{2} \mathrm{O}$ at $4^{\circ} \mathrm{C}$.

In all cases, following drying under a stream of cool air, the sections were stored with desiccant at $4^{\circ} \mathrm{C}$ overnight to remove any remaining moisture. The slides were placed in x-ray cassettes and tightly apposed to Ultrofilm (Leica) for varying times at room temperature. Low or high activity ${ }^{3} \mathrm{H}$-containing plastic standards (American Radiolabeled Chemicals, St. Louis, MO) were included with the tissue-mounted slides and apposed to film. Exposure times for each radioligand were as follows: $\left[{ }^{3} \mathrm{H}\right]$ ketanserin-incubated sections for 1 to 2 months; [ ${ }^{125}$ I]LSD-incubated sections for 72 hours; [H] 8-OH-DPAT-incubated sections for 60 days; and [PH]CN-IMI-incubated sections for 28 days. The film was then processed in Kodak GBX developer ( 3 minutes) and fixative (6 minutes).

\section{Data Analysis}

The illuminated image of each autoradiograph was collected by a video camera connected to an IBM AT-based image-analysis system (DUMAS, Drexel University, Philadelphia, PA). Because of nonlinearities in the film and image array processor, these original grey values werenot a linear function of the concentration of radioligand. Tritium-embedded plastic standards containing high concentrations of tritium were calibrated against ${ }^{125} \mathrm{I}$-containing tissue standards and used to transform the original grey value of each pixel to a linear function and expressed as the quantity of ${ }^{125}$ I-radioligand bound (Artymyshyn et al. 1990). The digitized images of the autoradiographs of total and nonspecific binding were displayed, the region of interest outlined, and the density of bound radioligand displayed for the region. Nonspecific binding was subtracted from total binding to obtain specific binding. The tissue sections used for the autoradiographic image were stained for Nissl after the development of the autoradiographic images, making them available for the visualization of brain nuclei. In addition, every 20th section directly processed for Nissl staining was used to clarify anatomic boundaries. The autoradiographic image was viewed in one frame and the histologic material in the other to facilitate accurate analysis of brain regions. Regions of the cortex were identified using the atlas of Nieuwenhuis and associates (1978). The regions of the parahippocampus, including entorhinal cortex and subfields of the hippocampus were identified with the aid of the atlas of Amaral and Insausti (1990). For the detailed mapping of $\left[{ }^{3} \mathrm{H}\right] \mathrm{CN}$-IMI binding in the striatum of control and schizophrenic cases additional information was obtained. Methods previously described for measuring the patch and matrix compartment-related binding of radioligands were used to delineate the pattern of $\left[{ }^{3} \mathrm{H}\right] \mathrm{CN}-\mathrm{IMI}$ binding in striatum (Joyce et al. 1992). Briefly, microzones high in the density of binding sites and the region surrounding the microzones (low in density) were outlined in four regions of the striatum (dorsal caudate nucleus, dorsal putamen, nucleus accumbens, ventral putamen) for at least four serial sections. The average density of the binding in the microzones and "surround" was determined for each striatal region.

For mapping studies a minimum of four sections per level were analyzed by region of brain. Average values were pooled for all cases by disease (treatment condition). Both hemispheres were available for only a few cases. For this reason, each hemisphere was treated as an independent sample for analysis of differences. Differences in the binding of $\left[{ }^{3} \mathrm{H}\right]$ ketanserin, [ $\left.{ }^{125} \mathrm{I}\right] \mathrm{LSD},\left[{ }^{3} \mathrm{H}\right] 8-\mathrm{OH}-\mathrm{DPAT}$, and $\left[{ }^{3} \mathrm{H}\right] \mathrm{CN}$-IMI between regions within disease groups and between disease groups were determined by two-factor analysis of variance with brain region as the repeated measure. Posthoc paired comparisons were tested for significance of difference using the method of Duncan (Snedecor and Cochran, 1967). Because fewer regions of brain were available for the suicide group, post-hoc paired comparisons were limited to control versus schizophrenia and control versus suicide.

\section{Materials}

Drugs were obtained from the pharmaceutical company of origin or from commercial sources. All radioligands, 
$\left[{ }^{3} \mathrm{H}\right]$ ketanserin $(61 \mathrm{Ci} / \mathrm{mmol}),\left[{ }^{125} \mathrm{I}\right] \mathrm{LSD}(2200 \mathrm{Ci} /$ $\mathrm{mmol}),\left[{ }^{3} \mathrm{H}\right] 8-\mathrm{OH}-D P A T(158 \mathrm{Ci} / \mathrm{mmol})$, and $\left[{ }^{3} \mathrm{H}\right] \mathrm{CN}$ IMI $(78.2 \mathrm{Ci} / \mathrm{mmol})$ were purchased from DuPont (New England Nuclear). The drugs mianserin (Organon, Oss, Netherlands), tripolidine (Sigma), prazosin (Sigma), ketanserin (Janssen, Beerse, Belgium), pargyline (Sigma), desipramine (Sigma), and 5-HT (Sigma) were obtained from their respective sources.

\section{RESULTS}

Preliminary experiments were performed to define optimal incubation procedures in which the binding of a range of concentrations of $\left[{ }^{3} \mathrm{H}\right]$ ketanserin, $\left[{ }^{125} \mathrm{I}\right] \mathrm{LSD}$, $\left[{ }^{3} \mathrm{H}\right] 8-\mathrm{OH}-\mathrm{DPAT}$, and $\left[{ }^{3} \mathrm{H}\right] \mathrm{CN}-\mathrm{IMI}$ to brain sections of rat $(n=4)$ and human frontal cortex $(n=6)$ was determined by liquid scintillation counting. The results indicated that the $K_{d}$ values were similar in rat and human tissue, but the $B_{\max }$ values were lower in the human tissue sections. For binding of $\left[{ }^{3} \mathrm{H}\right]$ ketanserin, [225I]LSD, $\left[{ }^{3} \mathrm{H}\right] 8-\mathrm{OH}-\mathrm{DPAT}$, and $\left[{ }^{3} \mathrm{H}\right] \mathrm{CN}-\mathrm{IMI}$ to human tissue sections, the $K_{d}$ values were, respectively, 0.81 $\mathrm{nmol} / \mathrm{L}$ (range 0.41 to $1.1 \mathrm{nmol} / \mathrm{L}$ ), $1.3 \mathrm{nmol} / \mathrm{L}$ (range 0.7 to $1.5 \mathrm{nmol} / \mathrm{L}$ ), $0.6 \mathrm{nmol} / \mathrm{L}$ (range 0.4 to $1.5 \mathrm{nmol} / \mathrm{L}$ ) and $0.14 \mathrm{nmol} / \mathrm{L}$ (range 0.08 to $0.15 \mathrm{nmol} / \mathrm{L}$ ). Comparison of the distribution of the radioligands indicated a unique pattern for each site in control brains. In the following sections, results obtained for the control group will be compared to those obtained from the other experimental groups for the striatum, regions of cortex, and the parahippocampal region (including hippocampus).

\section{Striatum}

The number of $\left[{ }^{3} \mathrm{H}\right] \mathrm{CN}$-IMI binding sites in the striatum of the control group was 5- to 10-fold higher than in any region of cortex $(p<.05)$. The highest number of sites was found in the putamen, with values significantly higher than in the caudate or nucleus accumbens $(p<.05$; Fig. 2$)$. The binding sites were particularly evident in the ventral putamen (Fig. 3A). As shown in Figure $3 \mathrm{~A}$, the topography of $\left[{ }^{3} \mathrm{H}\right] \mathrm{CN}$-IMI binding sites in the putamen was patchy with regions of dense binding (microzones) surrounded by regions of less dense binding (Table 2). Microzones of dense binding were also visible in the caudate nucleus but less apparent. For the control group, the number of $5-\mathrm{HT}_{1 \mathrm{~A}}$ receptors was considerably lower in the striatum than in the cortex (by 9- to 10-fold), and was homogeneously distributed (Figs. 2 and 3 C). Serotonin 2 receptor sites labeled with $\left[{ }^{3} \mathrm{H}\right]$ ketanserin (Figs. 2 and 3B) showed a relatively homogeneous distribution in the striatum. No significant difference in the amount of binding between the caudate, putamen, and nucleus accumbens was

\section{STRIATUM}
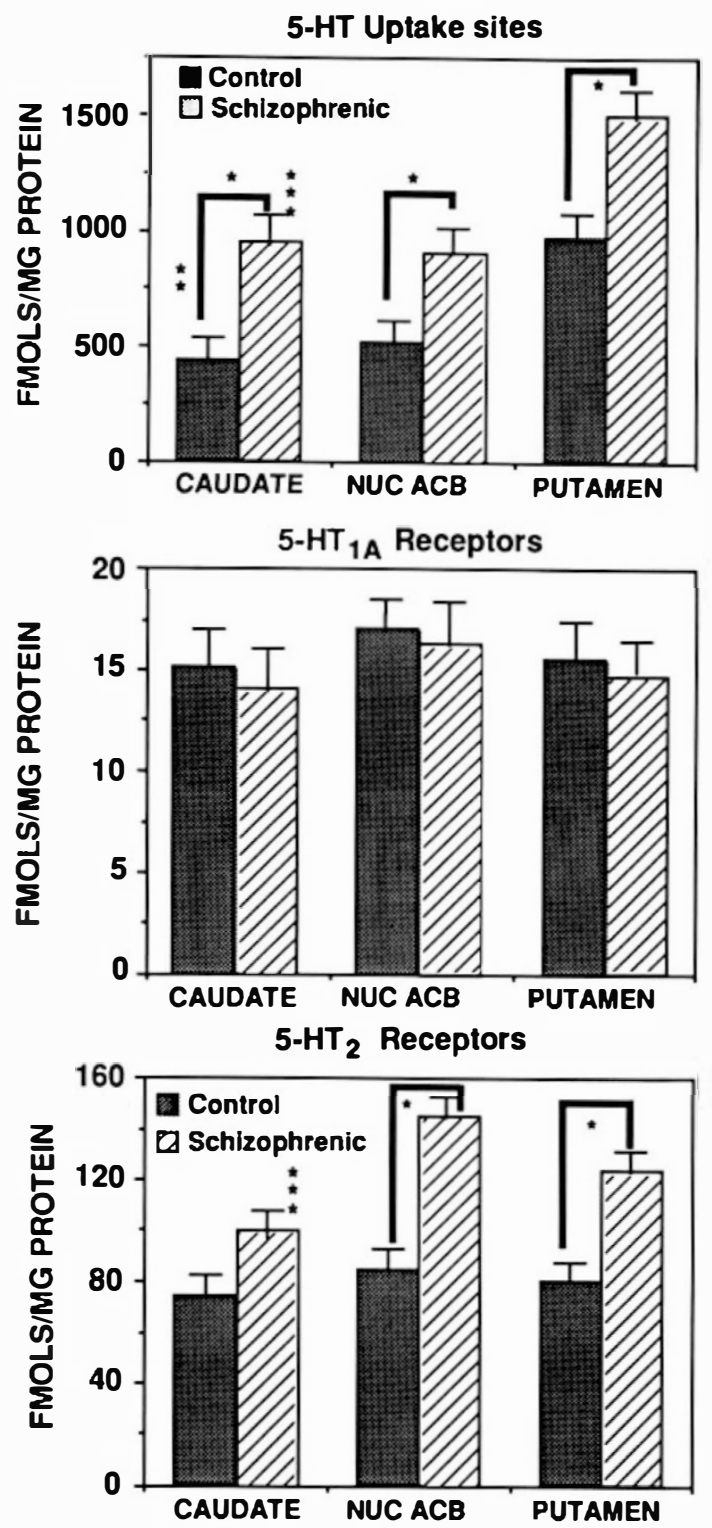

Figure 2. Bar graphs showing the mean number $( \pm S D) 0$ 5 -HT uptakes sites labeled with $\left[{ }^{3} \mathrm{H}\right] \mathrm{CN}$-IMI, 5- $\mathrm{HT}_{1 \mathrm{~A}}$ recep tors labeled with $\left[{ }^{3} \mathrm{H}\right] 8-\mathrm{OH}-\mathrm{DPAT}$, and $5-\mathrm{HT}_{2}$ receptors la beled with $\left[{ }^{3} \mathrm{H}\right]$ ketanserin for control and schizophreni groups for regions of the striatum. The schizophrenics showe significantly ( $p<.01$ indicated by bar and asterisk) elevate numbers of 5-HT uptake sites (between group effects, $p<.01$ all regions) and $5-\mathrm{HT}_{2}$ receptors (between group effects, $p$. .001; nucleus accumbens and putamen). For the schizophreni group 5-HT uptake sites were significantly higher in the puta men than the caudate or nucleusaccumbens (between regions $p<.05$ ) and 5- $\mathrm{HT}_{2}$ receptors were significantly higher in th nucleus accumbens and putamen than in the caudate (be tween regions, $p<.05)$. Abbreviations: Nuc Acb, nucleus ac cumbens. Between group differences are indicated by a sin gle asterisk, significant differences between regions for contrc group by double asterisk, and significant differences betwee regions for schizophrenic group by triple asterisk. 


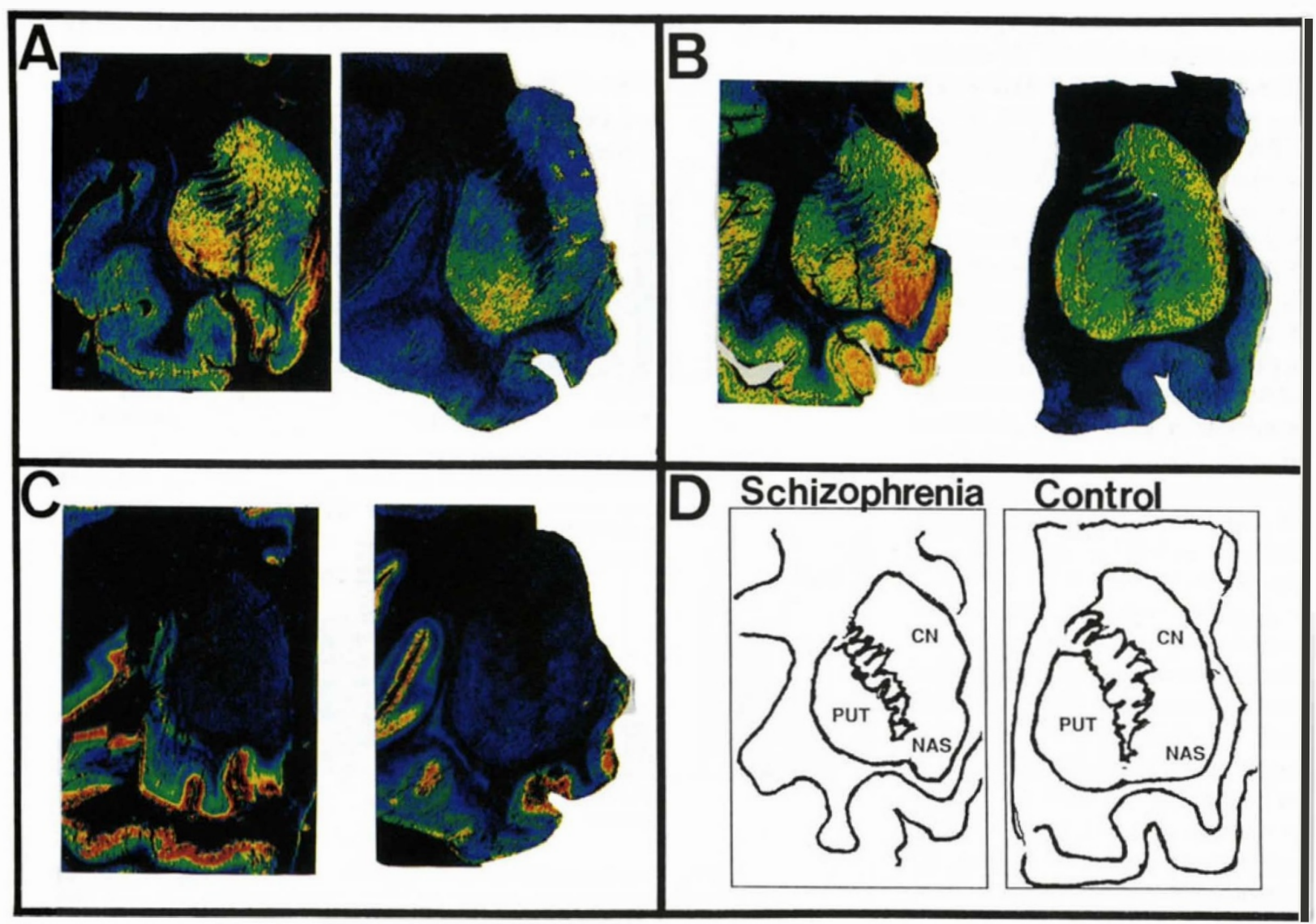

Figure 3. Pseudocolor images from autoradiographs representing the number of $5-\mathrm{HT}$ uptake sites labeled with [ $\left.{ }^{3} \mathrm{H}\right] \mathrm{CN}$ MI (A), 5- $\mathrm{HT}_{2}$ receptors labeled with [ $\left.{ }^{3} \mathrm{H}\right]$ ketanserin (B), and 5- $\mathrm{HT}_{1 \mathrm{~A}}$ receptors labeled with $\left[{ }^{3} \mathrm{H}\right] 8-\mathrm{OH}-\mathrm{DPAT}(\mathrm{C})$ for a control and a schizophrenic case for regions of the striatum. (D) The diagram of the striatum shows the location of the regions analyzed. Note larger zones of higher density of $\left[{ }^{3} \mathrm{H}\right] \mathrm{CN}$-IMI sites in the schizophrenic case in the ventral striatum and the existence of "microzones" of dense binding in the dorsal striatum (caudate nucleus and putamen) of the schizophrenic but not the control case. In contrast, $5-\mathrm{HT}_{2}$ receptors are increased in the ventral striatum (nucleus accumbens and ventral putamen). The pseudocolor coding for the density of binding sites at a single concentration is represented by red as the highest. Abbreviations: Nuc Acb, nucleus accumbens.

found. Similar results were obtained with [125I]LSD (data not shown). The number of sites labeled with a single concentration of [ ${ }^{125}$ I] LSD was higher in the striatum than that found in the hippocampus and entorhinal cortex but lower than that observed in most regions of cortex $(p<.05)$.

The striatum of the schizophrenic cases showed a different pattern of binding as compared to controls for $\mathrm{PH}] \mathrm{CN}-\mathrm{IMI}$ to $5-\mathrm{HT}$ uptake sites and of $\left[{ }^{3} \mathrm{H}\right]$ ketanserin binding to $5-\mathrm{HT}_{2}$ sites (Figs. 2 and 3). The number of 5-HT uptake sites was elevated in the striatum of the schizophrenic group by $60 \%$ to $100 \%$ as compared to the control group $(p<.01)$. As depicted in Figure 3A, the typical pattern in the control cases of highest binding in the ventral putamen still existed in the schizophrenic cases. However, the microzones of binding were significantly denser and greater in size (Table 2). In addi-
Table 2. Binding of $\left[{ }^{3} \mathrm{H}\right] \mathrm{CN}$-IMI to 5-HT Uptake Sites in Striatum ${ }^{a}$

\begin{tabular}{lccc}
\hline \multicolumn{1}{c}{ Region } & Entire Area & Surround & Microzone \\
\hline Control & & & \\
$\quad$ Dorsal-Cd & $476 \pm 95$ & $199 \pm 59$ & $637 \pm 222^{b}$ \\
Nuc Acb & $529 \pm 133$ & $227 \pm 91$ & $736 \pm 162^{b}$ \\
Dorsal-PUT & $424 \pm 112$ & $221 \pm 92$ & $633 \pm 178^{b}$ \\
$\quad$ Ventral-PUT & $1035 \pm 143$ & $423 \pm 232$ & $1341 \pm 193^{b}$ \\
& & & \\
Schizophrenia & & & \\
$\quad$ Dorsal-Cd & $988 \pm 143^{3}$ & $221 \pm 72$ & $1037 \pm 193^{b, c}$ \\
Nuc Acb & $839 \pm 133^{3}$ & $318 \pm 99$ & $1056 \pm 204^{b, c}$ \\
Dorsal-PUT & $1029 \pm 222^{3}$ & $299 \pm 102$ & $1639 \pm 203^{b, c}$ \\
$\quad$ Ventral-PUT & $1646 \pm 143^{3}$ & $421 \pm 273$ & $1965 \pm 213^{b, c}$ \\
\end{tabular}

${ }^{a}$ Values are presented as means $\pm \mathrm{SD} \mathrm{fmol} / \mathrm{mg}$ protein, $n=8$ for control and $n=10$ for schizophrenics.

${ }^{b} p<.05$ versus surround and entire area.

${ }^{c} p<.05$ versus control. 
Figure 4. Bar graphs showing the mean number $( \pm S D)$ number of 5-HT uptake sites labeled with $\left[{ }^{3} \mathrm{H}\right] \mathrm{CN}-\mathrm{IMI}$ (top), $5-\mathrm{HT}_{1 \mathrm{~A}}$ receptors labeled with $\left[{ }^{3} \mathrm{H}\right] 8$ OH-DPAT (middle), and $5-\mathrm{HT}_{2}$ receptors labeled with [ ${ }^{125} \mathrm{I}$ ]LSD (bottom) for control and schizophrenic groups for regions of the anterior cingulate cortex (ANT CING CORTEX) and prefrontal cortex. The locations of the regions analyzed are shown in Figure 1A. The schizophrenics showed reduced numbers of 5-HT uptake sites in laminae I-III of the anterior cingulate cortex (between groups, $p<.01$ ) and of laminae I-IV of prefrontal cortex (between groups, $p<$ $.01)$ as compared to the control group. The number of $5-\mathrm{HT}_{1 \mathrm{~A}}$ receptors was elevated in the laminae V-VI of the anterior cingulate cortex as compared to the control group (between groups, $p<$ .01). For the control group, 5-HT uptake sites were significantly higher in laminae I-III than laminae V-VI (between regions, $p<.01), 5-\mathrm{HT}_{1 \mathrm{~A}}$ receptors were higher in laminae I-II than III-VI (between regions, $p<.01$ ), and $5-\mathrm{HT}_{2}$ receptors higher in laminae III than all other laminae $(p<.001)$. For the schizophrenic group, $5-\mathrm{HT}_{1 \mathrm{~A}}$ receptors were higher in laminae I-II than III-VI (between regions, $p<.01$ ), and $5-\mathrm{HT}_{2}$ receptors higher in the intermediate laminae (IIIa,b,c, or III-IV) than all other laminae $(p<.001)$. Between group differences are indicated by single asterisk, significant differences between regions for control group by double asterisk, and significant differences between regions or schizophrenic group by triple asterisk.

\section{ANT CING CORTEX}
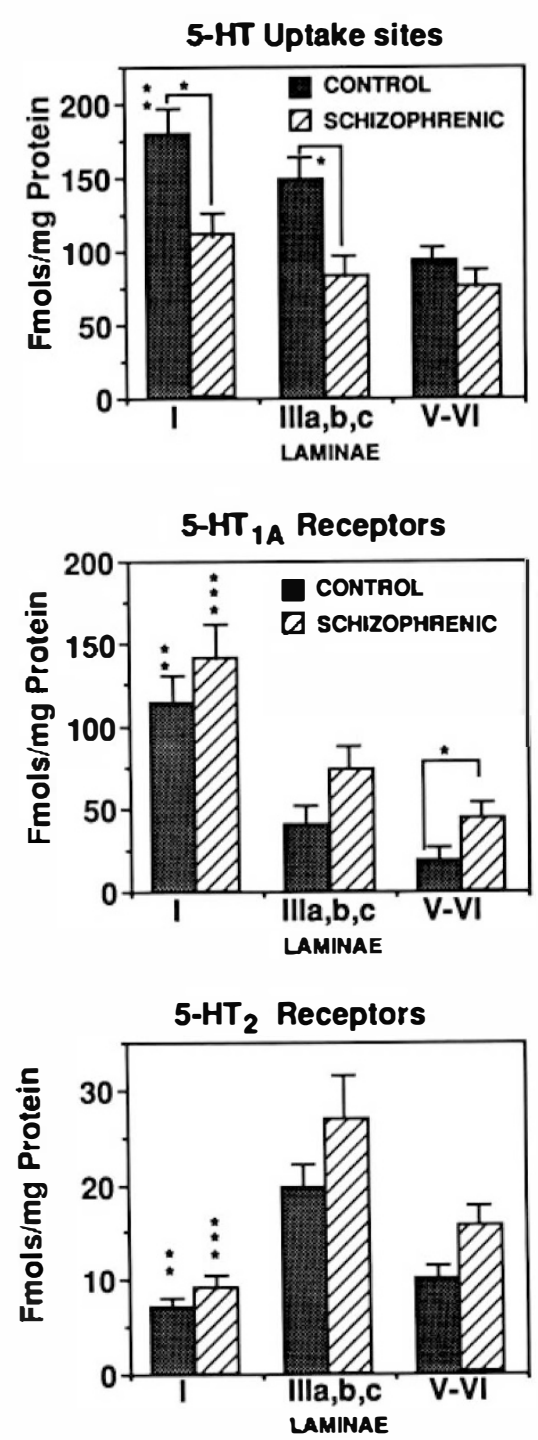

PREFRONTAL CORTEX
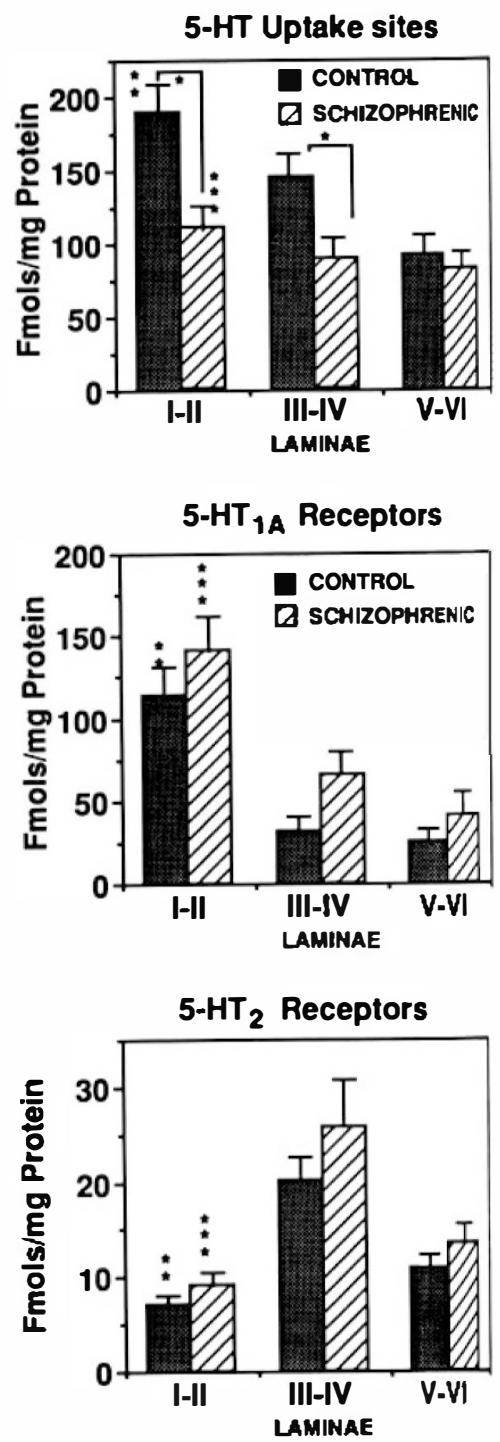

tion, microzones of dense binding were frequently observed in the dorsal putamen and in the caudate nucleus in the schizophrenics but not in the controls. The binding in the microzones, and not in the surrounding matrix, was significantly higher in the schizophrenics as compared to the controls in all regions of the striatum $\left(p<.01\right.$, Table 2). Binding of $\left[{ }^{3} \mathrm{H}\right]$ ketanserin (Figs. 2B and 3 ) and [ $\left.{ }^{125} \mathrm{I}\right]$ LSD (not shown) for $5-\mathrm{HT}_{2}$ sites was also elevated and the pattern of expression altered. Thus, the number of sites was significantly higher in the schizophrenic cases than the control cases in the nucleus accumbens $(p<.001)$ and putamen $(p<.001)$, but not for the caudate nucleus (Fig. 2B). The results of the saturation experiments indicated that the $\mathrm{K}_{\mathrm{d}}$ values for [ $\left.{ }^{125} \mathrm{I}\right]$ LSD binding to $5-\mathrm{HT}_{2}$ sites in the striatum of control and schizophrenic groups was similar and the values for the $B_{\max }$ altered $(p<.01)$. The control group had a $K_{d}$ value of $1 \mathrm{nmol} / \mathrm{L}$ (range 0.7 to 1.5 $\mathrm{nmol} / \mathrm{L}$ ) with a mean $B_{\max }$ of $62 \pm 13$ (SD) fmols/mg protein. The schizophrenic group had a $K_{d}$ of 1.4 $\mathrm{nmol} / \mathrm{L}(0.8$ to $1.5 \mathrm{nmol} / \mathrm{L})$ and a $B_{\max }$ of $117 \pm 12$ fmols/mg protein. No difference was observed for $\left[{ }^{3} \mathrm{H}\right] 8-\mathrm{OH}-\mathrm{DPAT}$ binding to $5-\mathrm{HT}_{1 \mathrm{~A}}$ receptors in schizophrenic cases as compared to controls (Figs. $2 \mathrm{C}$ and 3).

\section{Frontal, Premotor, and Motor Cortex}

For regions of cortex in control cases, $\left[{ }^{3} \mathrm{H}\right] \mathrm{CN}-\mathrm{M}$ labeling of 5-HT uptake sites was highest in the exter. nal laminae (laminae I and II) and lowest in laminze V and VI (Figs. 4 and 5). This pattern was most corr 


\section{CINGULATE CORTEX}
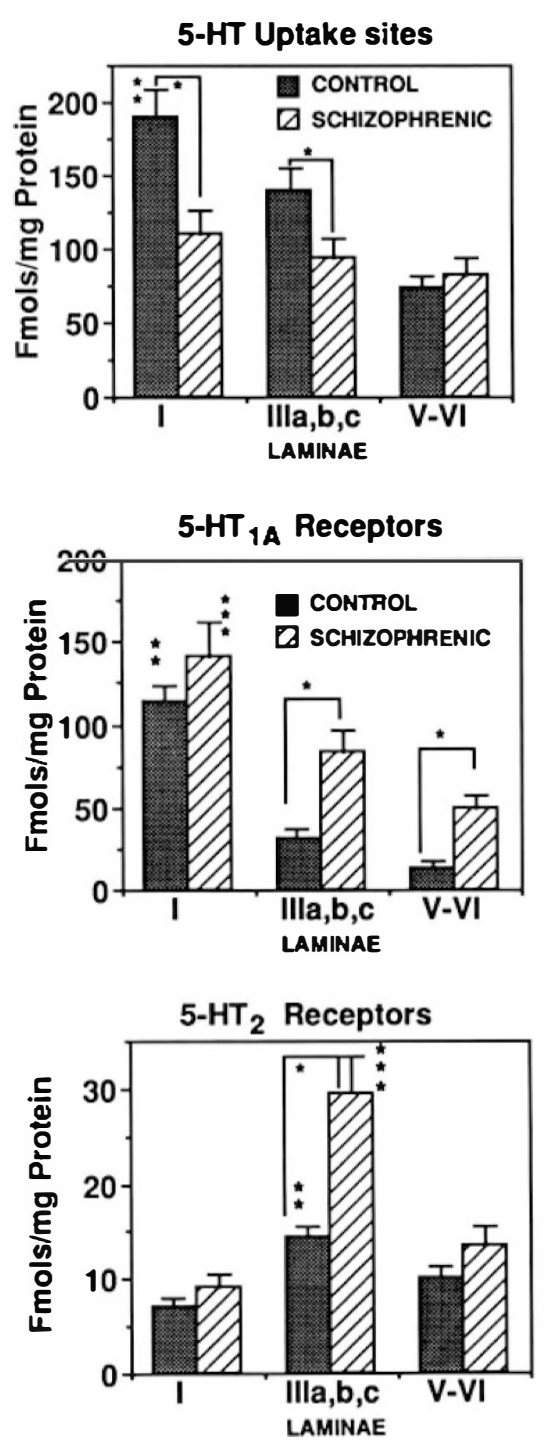

MOTOR CORTEX
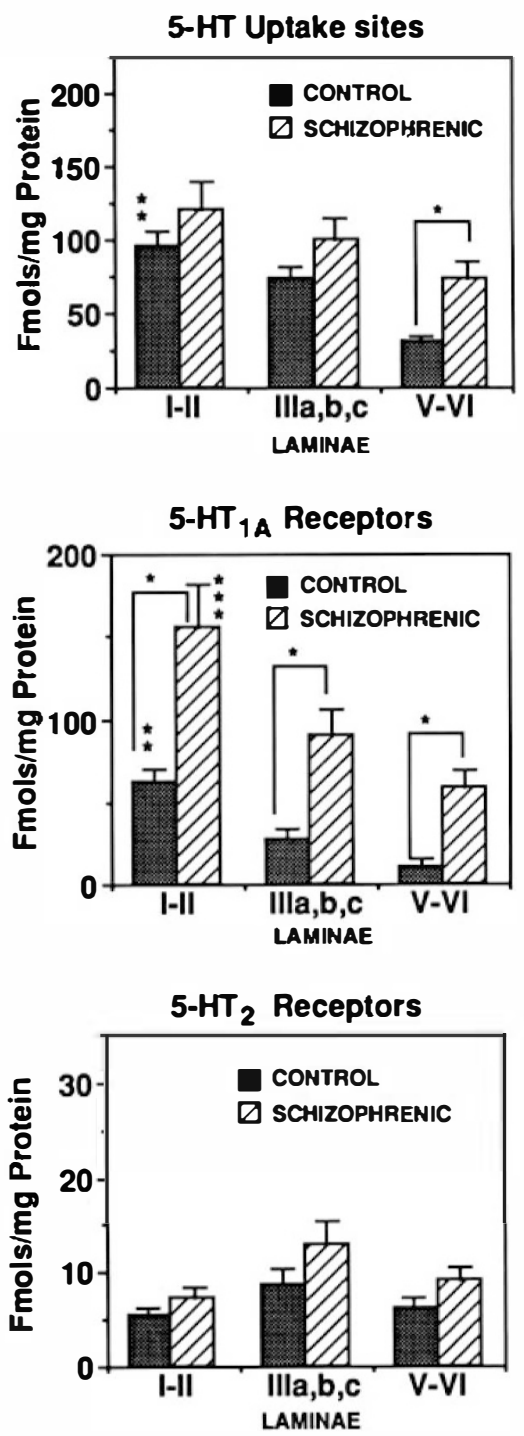

Figure 5. Bar graphs showing the mean number $( \pm \mathrm{SD})$ of 5 -HT uptake sites labeled with $\left[{ }^{3} \mathrm{H}\right] \mathrm{CN}-\mathrm{IMI}, 5-\mathrm{HT}_{1 \mathrm{~A}}$ receptors labeled with $\left[{ }^{3} \mathrm{H}\right] 8-\mathrm{OH}-\mathrm{DPAT}$, and $5-\mathrm{HT}_{2}$ receptors labeled with $\left.{ }^{125} \mathrm{I}\right] \mathrm{LSD}$ for control and schizophrenic groups for regions of the cingulate cortex and motor cortex. The locations of the regions analyzed are shown in Figure 1C. The schizophrenic group showed reduced numbers of 5-HT uptake sites in the laminae I-III of posterior cingulate cortex $(p<.001)$ and an elevation in the deep laminae of the motor cortex $(p<.01)$ as compared to the control group. The schizophrenic group showed elevated numbers of $5-\mathrm{HT}_{1 \mathrm{~A}}$ receptors in the laminae III and V-VI of posterior cingulate cortex $(p<.01)$ and all laminae of motor cortex $(p<.001)$ as compared to the control group. The number of $5-\mathrm{HT}_{2}$ receptors was elevated in the schizophrenic group in laminae III of posterior cingulate cortex $(p<.001)$ as compared to the control group. Within the cingulate cortex, the control group showed higher numbers of 5-HT uptake sites for laminae I-II than IIIa,b,c, which is greater than laminae $\mathrm{V}$-VI (between regions, $p<.01$ ). Serotonin ${ }_{1 \mathrm{~A}}$ receptors were higher in laminae I-II than IIIa, $\mathrm{b}, \mathrm{c}$, which is greater than laminae V-VI (between regions, $p<.01$ ), and 5- $\mathrm{HT}_{2}$ receptors higher in laminae III than all other laminae $(p<.001)$. For the schizophrenic group, $5-\mathrm{HT}_{1 \mathrm{~A}}$ receptors were higher in laminae I-II than III-VI (between regions, $p<.01$ ), and 5- $\mathrm{HT}_{2}$ receptors higher in laminae IIIa,b,c than all other laminae $(p<.001)$. Within the motor cortex, the control group showed lower numbers of 5-HT uptake sites for laminae V-VI than all other laminae (between regions, $p<.01$ ). Serotonin $1 \mathrm{~A}$ receptors were higher in laminae I-II than IIIa,b,c, which is greater than laminae V-VI (between regions, $p<.01$ ). For the schizophrenic group, $5-\mathrm{HT}_{1 \mathrm{~A}}$ receptors were higher in laminae I-II than IIIa,b,c, which is greater than laminae $\mathrm{V}$-VI (between regions, $p<$ .01). Abbreviations: CINGULATE CORTEX, posterior cingulate cortex. Between group differences are indicated by single asterisk, significant differences between regions for control group by double asterisk, and significant differences between regions for schizophrenic group by triple asterisk. 
TEMPORAL CORTEX
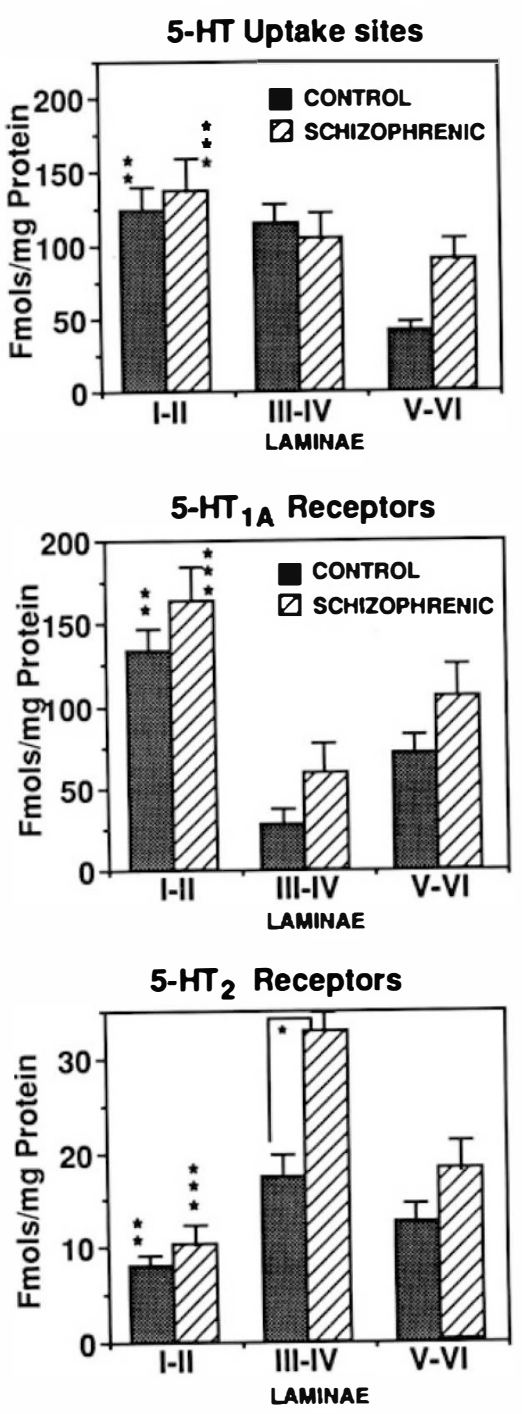

ENTORHINAL CORTEX
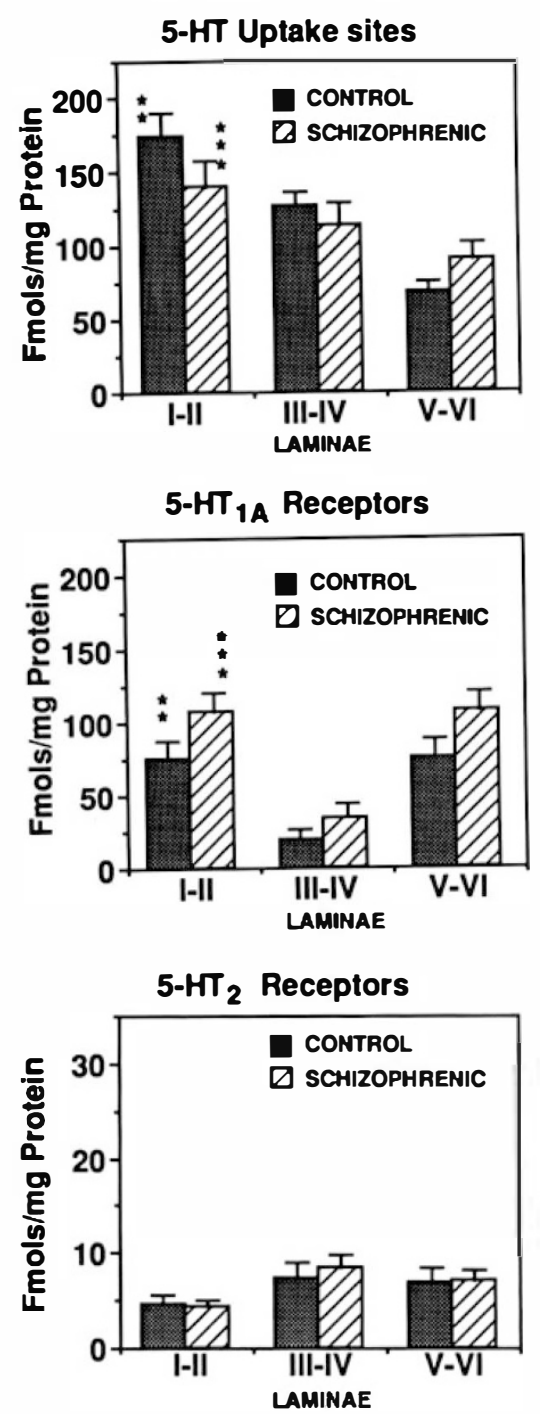

Figure 6. Bar graphs showing the mean number $( \pm \mathrm{SD})$ of 5 -HT uptake sites labeled with $\left[{ }^{3} \mathrm{H}\right] \mathrm{CN}-\mathrm{IMI}, 5-\mathrm{HT}{ }_{1 \mathrm{~A}}$ receptors labeled with [ $\left.{ }^{3} \mathrm{H}\right] 8-\mathrm{OH}-\mathrm{DPAT}$, and 5- $\mathrm{HT}_{2}$ receptors labeled with [ $\left.{ }^{125} \mathrm{I}\right] \mathrm{LSD}$ for control and schizophrenic groups for regions of the temporal cortex and entorhinal cortex. The locations of the regions analyzed are shown in Figure $1 \mathrm{C}$. The schizophrenic group showed elevated numbers of $5-\mathrm{HT}_{2}$ receptors in laminae III-IV of the temporal cortex (between group, $p<.001$ ). Within the temporal cortex, the control group exhibited higher numbers of 5-HT uptake sites for laminae I-II than III-IV, which was greater than laminae V-VI (between regions, $p<.01$ ). Serotonin 1 A receptors were higher in laminae I-II than $\mathrm{V}-\mathrm{VI}$, which is greater than laminae III-IV (between regions, $p<.01$ ), and 5- $\mathrm{HT}_{2}$ receptors were higher in laminae III-IV than all other laminae $(p<.001)$. For the schizophrenic group, 5- $\mathrm{HT}_{1 \mathrm{~A}}$ receptors were higher in laminae I-II than $\mathrm{V}-\mathrm{VI}$, which is greater than laminae III-IV (between regions, $p<.01$ ), and 5-HT2 receptors were higher in laminae III-IV than $\mathrm{V}-\mathrm{VI}$, which is higher than laminae I-II $(p<.01)$. Within the entorhinal cortex, the control group showed higher numbers of 5-HT uptake sites in laminae I-II than III-IV, which is greater than laminae V-VI (between regions, $p<.01$ ). SerotoniniA receptors were lower in laminae III-IV than I-II or V-VI (between regions, $p<.01$ ). For the schizophrenic group, 5-HT uptake sites were higher in laminae I-IV than V-VI (between regions, $p<.01$ ), $5-\mathrm{HT}_{1 \mathrm{~A}}$ receptors were lower in laminae III-IV than I-II or V-VI (between regions, $p<.01$ ). Between group differences are indicated by single asterisk, significant differences between regions for control group by double asterisk, and significant differences between regions for schizophrenic group by triple asterisk.

spicuous in the anterior cingulate (laminae I $>$ laminae V-VI; $p<.01$ ), frontal (laminae I-II > III-IV > V-VI; $p<.01$ ), posterior cingulate (laminae I > III-IV $>$ V-VI; $p<.01$ ), and parietal cortices (data not shown) and least distinct in motor cortex (laminae I-II $>$ V-VI; $p<.01$ ). In most of the cortices the pattern of $\left[{ }^{3} \mathrm{H}\right] 8-\mathrm{OH}-\mathrm{DPAT}$ binding of $5-\mathrm{HT}_{1 \mathrm{~A}}$ receptors closely followed that of the 5-HT uptakes sites with $\left[{ }^{3} \mathrm{H}\right] 8-\mathrm{OH}-\mathrm{DPAT}$ binding 
to $5-\mathrm{HT}_{1 \mathrm{~A}}$ receptors highest in the upper laminae, being more than twofold greater in number than the middle and inner laminae (Figs. 4 and 5). This was evident in the anterior cingulate (laminae I $>$ laminae V-VI; $p<$ .01 ), frontal (laminae I-II $>$ III-IV $=$ V-VI; $p<.01$ ), posterior cingulate (laminae I $>$ III-IV $>V-V I ; p<.01$ ), and parietal (laminae I $>$ III-IV $>$ V-VI; $p<.01$, data not shown) cortices, but less so for the motor cortex (laminae I-II $>$ III $>$ V-VI; $p<.05$ ). The labeling of 5- $\mathrm{HT}_{2}$ receptors with [ $\left.{ }^{125} \mathrm{I}\right] \mathrm{LSD}$ was more than twofold higher in the middle laminae (layers III and IV) than the deep laminae and slightly higher in the deep than the superficial laminae of anterior cingulate $(p<.001)$, frontal $(p<.001)$, posterior cingulate $(p<.05)$, and parietal $(p<.05)$ cortices. In motor cortex the pattern of $5-\mathrm{HT}_{2}$ receptors did not differ by laminae (Fig. 5).

For the schizophrenic cases, binding of $\left[{ }^{3} \mathrm{H}\right] \mathrm{CN}-$ IMI to 5 -HT uptake sites was reduced by $51 \%$ to $76 \%$ as compared to control cases in the external and middle laminae of some cortical regions, including the anterior cingulate (schizophrenic $<$ control; $p<.01$; Fig. 4), Frontal cortex (schizophrenic < control; $p<.01$; Fig. 4), and posterior cingulate (schizophrenic $<$ control; $p<$ .01; Fig. 5), but not in the motor cortex or parietal cortex (or temporal cortex, see below). Consequently, there was no significant difference among laminae of the anterior cingulate, frontal cortex, and posterior cingulate cortices of the schizophrenic group. Comparison of the schizophrenic to the control group demonstrated better than a threefold elevation in the binding of $\left[{ }^{3} \mathrm{H}\right] 8$ $\mathrm{OH}-\mathrm{DPAT}$ binding to $5-\mathrm{HT}_{1 \mathrm{~A}}$ receptors in the cingulate (schizophrenic $>$ control; $p<.01$; Figs. 4 and 5) and motor cortex (schizophrenic $>$ control; $p<.001$; Fig. 5) but not in the frontal (Fig. 4), or parietal cortices (or temporal cortex, see below). In the anterior cingulate, the increase was significant only for the deep laminae $(p<$ .01 ), whereas both middle and deep laminae of the posterior cingulate showed better than twofold higher numbers of $5-\mathrm{HT}_{1 \mathrm{~A}}$ receptors $(p<.01)$ in the schizophrenic group as compared to the control group. All laminae of the motor cortex show two- to threefold increases in binding of $\left[{ }^{3} \mathrm{H}\right] 8-\mathrm{OH}-\mathrm{DPAT}(p<.01)$ in the schizophrenic group as compared to the control group. However, the laminar arrangement of $5-\mathrm{HT}_{1 \mathrm{~A}}$ receptors was not altered in any cortical region of the schizophrenic cases. [ $\left.{ }^{125} \mathrm{I}\right] \mathrm{LSD}$ binding to $5-\mathrm{HT}_{2}$ sites was also elevated in the middle laminae of the posterior cingulate (schizophrenic $>$ control; $p<.001$; Fig. 5) but not in the frontal, anterior cingulate, or motor cortices.

\section{Temporal Cortex and Hippocampus}

In most regions of the temporal lobe of the control cases, the pattern of 5-HT uptake sites was similar to that in frontal cortex with the external laminae exhibiting the highest binding of $\left[{ }^{3} \mathrm{H}\right] \mathrm{CN}-\mathrm{IMI}$ (laminae I-II > V-VI; $p<.01)$. In the superior, middle, and inferior lobes of the temporal cortex, the binding of $\left[{ }^{3} \mathrm{H}\right] 8-\mathrm{OH}-\mathrm{DPAT}$ was trilaminar with the binding highest in the external laminae and lowest in the middle laminae (laminae I-II $>\mathrm{V}-\mathrm{VI}>\mathrm{III} ; p<.01$; Fig. 6). As in the frontal cortex, [ $\left.{ }^{125} \mathrm{I}\right] \mathrm{LSD}$-labeled $5-\mathrm{HT}_{2}$ receptors were highest in number in the middle laminae (laminae III-IV $>$ I-II $=$ V-VI; $p<.01$; Fig. 6). In the medial temporal lobe of the control cases (entorhinal cortex) $\left[{ }^{3} \mathrm{H}\right] \mathrm{CN}$-IMI binding to 5-HT uptake sites was most abundant in number in the external laminae and the relative numbers similar to other regions of temporal cortex (laminae I-II $>$ V-VI; $p<.01 ;$ Fig. 6). In contrast, the laminar distribution of $5-\mathrm{HT}_{2}$ receptors in this same region was indistinct with relatively low numbers of sites when compared to other regions of temporal cortex (Fig. 6). The binding of $\left[{ }^{3} \mathrm{H}\right] 8-\mathrm{OH}-\mathrm{DPAT}$ to $5-\mathrm{HT}_{1 \mathrm{~A}}$ receptors was nearly equivalent in the upper and deep laminae and quite low in the middle laminae of the entorhinal cortex (laminae III, IV > I, II and V-VI; $p<.01$; Fig. 6). The binding in the region immediately adjacent to the entorhinal cortex, the perirhinal or lateral occipitotemporal cortex, showed significantly higher binding of both $\left[{ }^{3} \mathrm{H}\right] 8-\mathrm{OH}-\mathrm{DPAT}$ (laminae I-II $>\mathrm{V}$-VI $>$ III; $p<$ .01 ) and [ $\left.{ }^{125} \mathrm{I}\right] \mathrm{LSD}$ (laminae III-IV $>$ I-II $=\mathrm{V}-\mathrm{VI} ; p<$ .001) with patterns similar to the remainder of the temporal cortex.

The pattern of an overlapping organization of 5- $\mathrm{HT}_{1 \mathrm{~A}}$ receptors and 5-HT uptake sites as well as a complementary organization of $5-\mathrm{HT}_{1 \mathrm{~A}}$ receptors and $5-\mathrm{HT}_{2}$ receptors, observable in most cortical regions of control cases, was not observed in the hippocampus. There appeared to be a reverse pattern of 5-HT uptake sites and 5-HT receptors, which was particularly evident for the distribution of $5-\mathrm{HT}_{1 \mathrm{~A}}$ receptors as compared to 5-HT uptake sites (Fig. 7). Regions of the parahippocampus and hippocampus that were low in the number of $\left[{ }^{3} \mathrm{H}\right] \mathrm{CN}$-IMI-labeled sites (Figs. 7A and 9), such as the subiculum and $\mathrm{CA}_{1}$ subfield, were highest in the number of $5-\mathrm{HT}_{1 \mathrm{~A}}$ receptors labeled with $\left[{ }^{3} \mathrm{H}\right] 8$ OH-DPAT (Figs. 7C, 8B, and 9). Conversely, in the dentate gyrus (DG), relatively high numbers of 5-HT uptake sites and low numbers of $5-\mathrm{HT}_{1 \mathrm{~A}}$ receptors were apparent. Thus, $\left[{ }^{3} \mathrm{H}\right] \mathrm{CN}$-IMI-labeled sites were significantly higher in the $D G$ than the $\mathrm{CA}_{3}$ or $\mathrm{CA}_{1}$ subfields $(p<.01)$, and $\left[{ }^{3} \mathrm{H}\right] 8-\mathrm{OH}-\mathrm{DPAT}$ binding was higher in the $\mathrm{CA}_{1}$ than DG $(p<.01)$. The distribution of $5-\mathrm{HT}_{2}$ receptors largely paralleled that of $5-\mathrm{HT}_{1 \mathrm{~A}}$ receptors in the main body of the hippocampus (Figs. $8 \mathrm{~A}$ and 9), but not in the rostral hippocampus (Fig. 7B). In the rostral hippocampus, low levels of [ ${ }^{125}$ I]LSD binding were present and inverse patterns to that of $\left[{ }^{3} \mathrm{H}\right] 8-\mathrm{OH}-\mathrm{DPAT}$ binding. In contrast, in the main body of the hippocampus relatively high numbers of $5-\mathrm{HT}_{1 \mathrm{~A}}$ receptors and $5-\mathrm{HT}_{2}$ receptors were found in the pyramidal layer of the $\mathrm{CA}_{1}$ subfield, lower in stri- 
Figure 7. Pseudocolor images from autoradiographs representing the number of 5-HT uptake sites labeled with $\left[{ }^{3} \mathrm{H}\right] \mathrm{CN}-\mathrm{IMI}(\mathrm{A}), 5-\mathrm{HT}_{2}$ receptors labeled with $\left[{ }^{125} \mathrm{I}\right] \mathrm{LSD}(\mathrm{B})$, and $5-\mathrm{HT}_{1 \mathrm{~A}}$ receptors labeled with $\left[{ }^{3} \mathrm{H}\right] 8-\mathrm{OH}$-DPAT (C) for a control case for regions of the rostral hippocampus. (D) The diagram of the hippocampus shows the locations of the regions analyzed. The pseudocolor coding for the number of binding sites at a single concentration is represented by red as the highest. Note that in the entorhinal cortex, the density of receptors is low and the number of uptake sites relatively high, but in the CA1 subfield of the hippocampus, the opposite pattern exists with $\left[{ }^{3} \mathrm{H}\right] 8-\mathrm{OH}-\mathrm{DPAT}$-labeled $5-\mathrm{HT}_{1 \mathrm{~A}}$ receptors high in number and 5-HT uptake sites low. However, 5- $\mathrm{HT}_{2}$ receptors in the rostral hippocampus were low in number and the pattern inverse to that of $\left[{ }^{3} \mathrm{H}\right] 8-\mathrm{OH}-\mathrm{DPAT}$ binding (this figure) but overlap with $5-\mathrm{HT}_{1 \mathrm{~A}}$ receptors in more caudal regions of the hippocampus (see Fig. 8). Abbreviations: EC, entorhinal cortex; Hi, hippocampus; TC, temporal cortex.

Figure 8. Pseudocolor images from autoradiographs representing the relative number of $5-\mathrm{HT}_{1 \mathrm{~A}}$ receptors labeled with $\left[{ }^{3} \mathrm{H}\right] 8-\mathrm{OH}$ $\operatorname{DPAT}(\mathrm{A}, \mathrm{B})$ and 5- $\mathrm{HT}_{2}$ receptors labeled with $\left[{ }^{125} \mathrm{I}\right] \mathrm{LSD}(\mathrm{C}, \mathrm{D})$, for a control case $(\mathrm{A}, \mathrm{C})$ and for a schizophrenic case (B, D) for hippocampus and temporal cortex. The diagrams $(E, F)$ of the temporal cortex, parahippocampus, and hippocampusshow the locations of the regions analyzed. Note the marked elevation of $5-\mathrm{HT}_{2}$ receptors in the temporal cortex, the smaller elevation in the hippocampus, and no change in the entorhinal cortex of the schizophrenic group. The number of $5-\mathrm{HT}_{1 \mathrm{~A}}$ receptors was elevated in the hippocampus, particularly the DG, but not in the entorhinal cortex or temporal cortex. The pseudocolor coding for the number of binding sites at a single concentration is represented by red as the highest. Abbreviations: EC, entorhinal cortex, $\mathrm{Hi}$, hippocampus; $\mathrm{TC}$, temporal cortex.
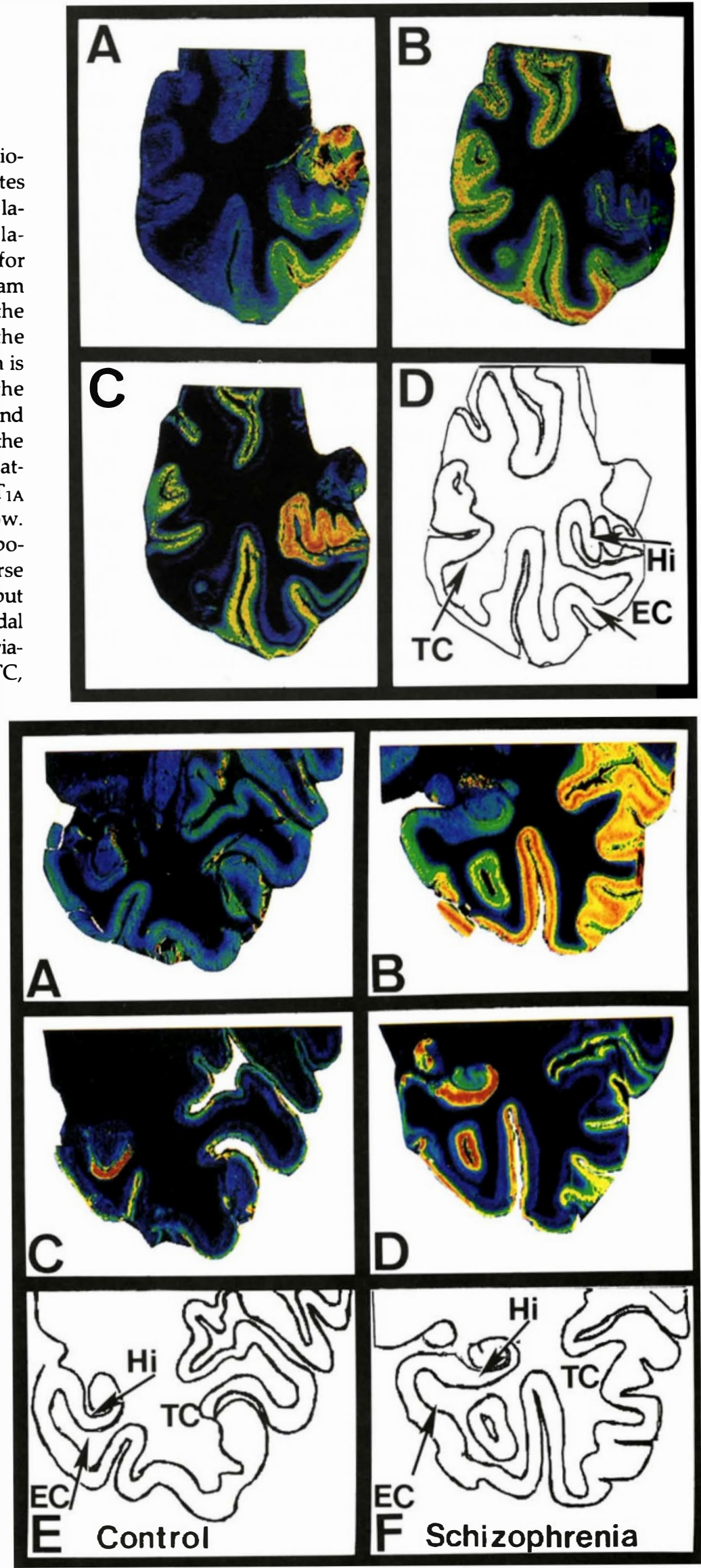


\section{HIPPOCAMPUS:SCHIZOPHRENIA}
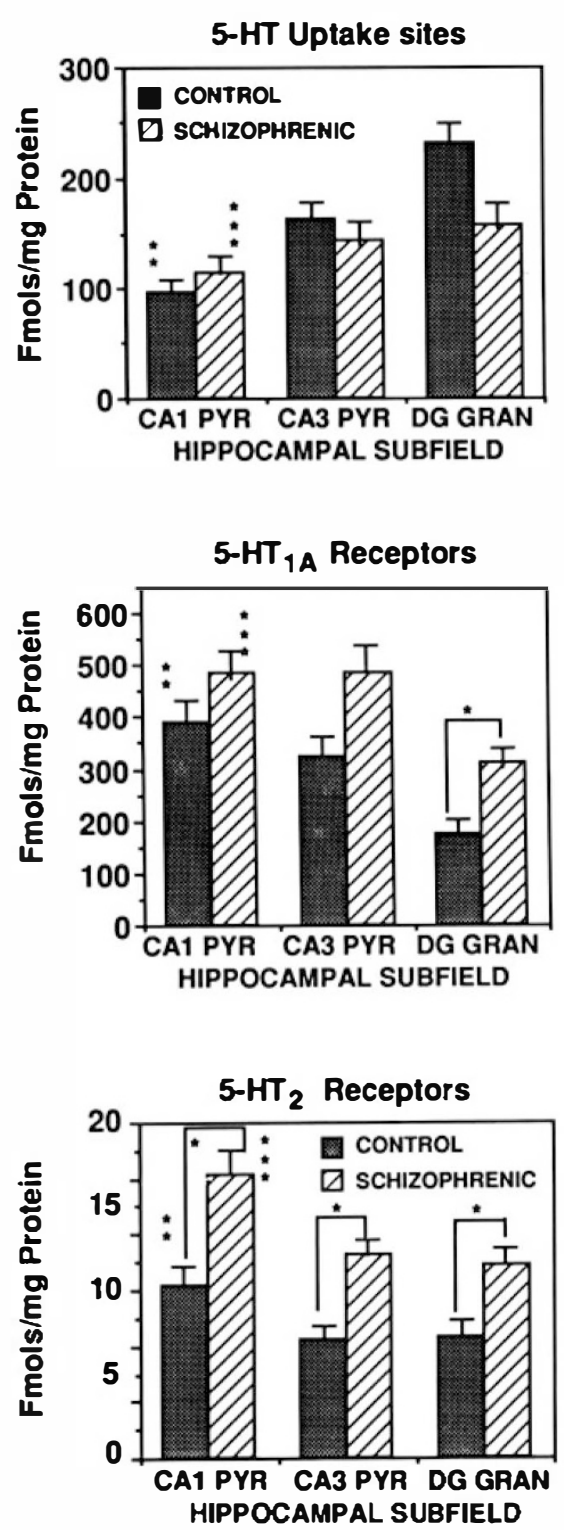

HIPPOCAMPUS:SUICIDE
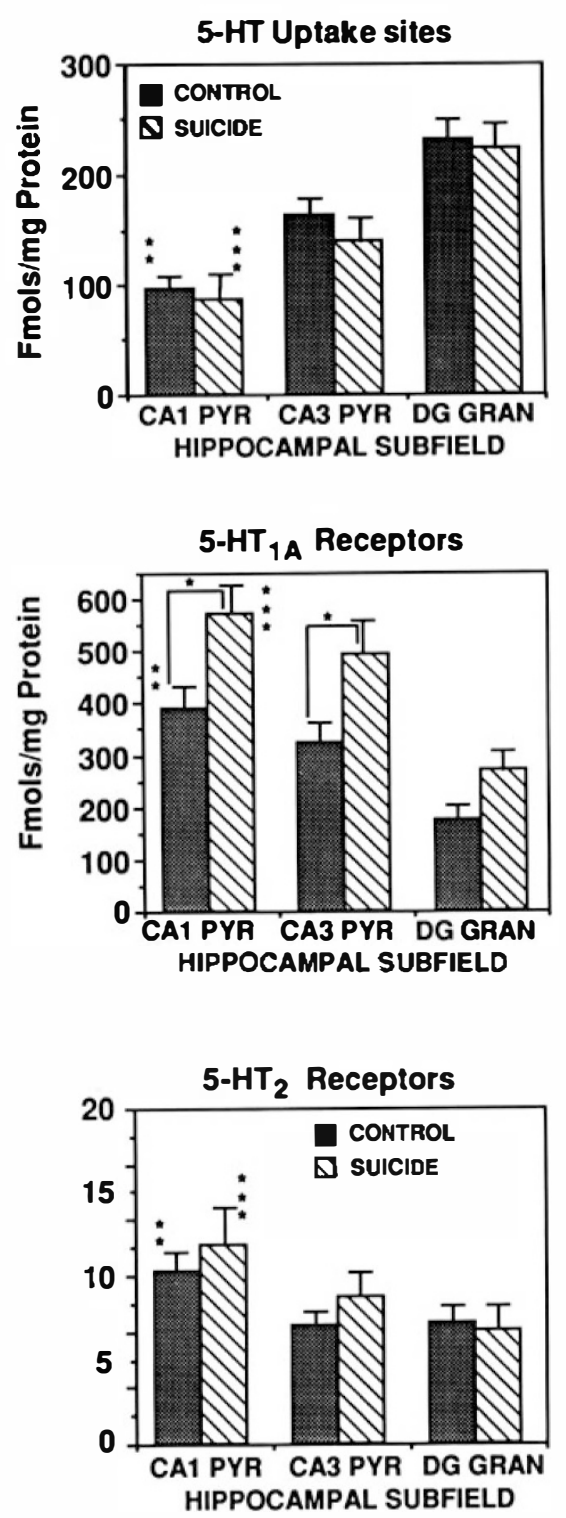

Figure 9. Bar graphs showing the mean number $( \pm \mathrm{SD})$ of $5-\mathrm{HT}$ uptake sites labeled with $\left[{ }^{3} \mathrm{H}\right] \mathrm{CN}-\mathrm{IMI}, 5-\mathrm{HT}_{1 \mathrm{~A}}$ receptors labeled with $\left[{ }^{3} \mathrm{H}\right] 8-\mathrm{OH}-\mathrm{DPAT}$, and 5-HT 2 receptors labeled with $\left[{ }^{125} \mathrm{I}\right] \mathrm{LSD}$ for control and schizophrenic (left panel), and for control and suicide groups (right panel) for regions of the hippocampus. The locations of the regions analyzed are shown in Figure 1D. The schizophrenic group exhibited elevated numbers of 5- $\mathrm{HT}_{2}$ receptors in all hippocampal subfields (between groups, $p<.01$ ) and $5-\mathrm{HT}_{1 \mathrm{~A}}$ receptors in the DG (between groups, $p<.01$ ) of the hippocampus as compared to the control group. The suicide group showed increases in $5-\mathrm{HT}_{1 \mathrm{~A}}$ receptors in subfields $\mathrm{CA}_{1}-\mathrm{CA}_{3}$ as compared to the control group (between groups, $p<.01$ ). The control group had higher numbers of 5 -HT uptake sites in DG than $\mathrm{CA}_{3}$, which is higher than $\mathrm{CA}_{1}$, higher numbers of $5-\mathrm{HT}_{1 \mathrm{~A}}$ receptors in $\mathrm{CA}_{1}$ than $\mathrm{CA}_{3}$, which is higher than $\mathrm{DG}$, and higher numbers of 5- $\mathrm{HT}_{2}$ receptors in $\mathrm{CA}_{1}$ than all hippocampal subfields (between regions, $p<.01$ ). The schizophrenic group showed fewer 5-HT uptake sites in the $\mathrm{CA}_{1}$ than all other hippocampal subfields, fewer $5-\mathrm{HT}_{1 \mathrm{~A}}$ receptors in DG than all other hippocampal subfields, and higher numbers of 5- $\mathrm{HT}_{2}$ receptors in $\mathrm{CA}_{1}$ than all hippocampal subfields (between regions, $p<.01$ ). The suicide group demonstrated higher numbers of 5-HT uptake sites in DG than $\mathrm{CA}_{3}$, which is higher than $\mathrm{CA}_{1}$, fewer numbers of 5-HT $\mathrm{HA}_{1 \mathrm{~A}}$ receptors in DG than all hippocampal subfields, and higher numbers of 5- $\mathrm{HT}_{2}$ receptors in $\mathrm{CA}_{1}$ than all hippocampal subfields (between regions, $p<.01)$. The number of sites for the pyramidal cell layer of $\mathrm{CA}_{1}\left(\mathrm{CA}_{1} \mathrm{PYR}\right)$ and $\mathrm{CA}_{3}\left(C A_{3} \mathrm{PYR}\right)$ is shown, and the granule cell layer of the dentate gyrus (DG GRAN). Between group differences are indicated by single asterisk, significant differences between regions for control group by double asterisk, and significant differences between regions for the schizophrenic (left panel) or suicide (right panel) groups by triple asterisk. 
atum oriens, and lowest in the $\mathrm{CA}_{3}$ subfield and DG (compare Figs. 7 and 8). To determine if this inconsistency between the rostral and main body of the hippocampus reflected labeling of sites other than $5-\mathrm{HT}_{2}$ receptors by $\left[{ }^{125} \mathrm{I}\right] \mathrm{LSD}$, the binding of $\left[{ }^{3} \mathrm{H}\right]$ ketanserin and [ $\left.{ }^{125} \mathrm{I}\right] \mathrm{LSD}$ for $5-\mathrm{HT}_{2}$ sites was compared. Only in the molecular layer of the DG and moleculare radiatum of the $\mathrm{CA}_{1}$ of the hippocampus was the binding of [ $\left.{ }^{125} \mathrm{I}\right] \mathrm{LSD}$ not displaced by ketanserin, nor was there significant $\left[{ }^{3} \mathrm{H}\right]$ ketanserin binding. Thus, if anything, the amount of $5-\mathrm{HT}_{2}$ receptors was overestimated in the DG with [125I]LSD. Therefore, the observed differences in the degree of overlap for $5-\mathrm{HT}_{1 \mathrm{~A}}$ receptors and $5-\mathrm{HT}_{2}$ receptors in the rostral and midbody of the hippocampus must be accounted for by other factors.

The schizophrenic and suicide cases were compared with the controls for the number of sites labeled with [ $\left.{ }^{125} \mathrm{I}\right] \mathrm{LSD},\left[{ }^{3} \mathrm{H}\right] 8-\mathrm{OH}-\mathrm{DPAT}$, and $\left[{ }^{3} \mathrm{H}\right] \mathrm{CN}$-IMI in the temporal cortex and hippocampus. Labeling of 5-HT uptake sites with $\left[{ }^{3} \mathrm{H}\right] \mathrm{CN}$-IMI was not reduced in the temporal cortex (Fig. 6), entorhinal cortex (Fig. 6), or hippocampus (Fig. 9) of the schizophrenic cases as compared to control cases. In contrast, 5-HT uptake sites were significantly reduced in number for the suicide group as compared to the controlgroup within the temporal cortex (suicide $<$ control; $p<.01$; Fig. 10) and entorhinal cortex (suicide $<$ control; $p<.01$; Fig. 10). The reduction in the suicide cases was significant only for the upper and middle laminae of the temporal cortex $(p<.01)$. Although $\left[{ }^{3} \mathrm{H}\right] 8-\mathrm{OH}-\mathrm{DPAT}$ binding to 5 - $\mathrm{HT}_{1 \mathrm{~A}}$ receptors was unchanged in the temporal cortex of schizophrenics (Fig. 6) and suicide cases (Fig. 10) as compared to the controls, there was an elevation in the entorhinal cortex of the suicide cases as compared to controls (suicide > control; $p<.001$; Fig. 10). The increase in $\left[{ }^{3} \mathrm{H}\right] 8-\mathrm{OH}-D P A T$ binding was significant for all laminae of the temporal cortex $(p<.001)$. The number of $5-\mathrm{HT}_{1 \mathrm{~A}}$ receptors was increased in the hippocampus of schizophrenic and suicide cases as compared to controls (Fig. 9), but the patterns of increased binding were not similar in the schizophrenic and suicide cases. The increase in $5-\mathrm{HT}_{1 \mathrm{~A}}$ receptors was significant for the DG of the schizophrenic group as compared to the control group $(p<.01)$ and for the $\mathrm{CA}_{1}-\mathrm{CA}_{3}$ subfields of the suicide group as compared to the control group $(p<.01)$. The schizophrenic cases showed an elevation in 5- $\mathrm{HT}_{2}$ receptors (Fig. 8) in the middlelaminae of the temporal cortex (schizophrenia $>$ control; $p<.05$; Fig. 6) and hippocampus as compared to controls (schizophrenia >control; $p<.01$; Fig. 9) but not in the entorhinal cortex (Figs. 6 and 8). Saturation assays of the binding of [ $\left.{ }^{125} \mathrm{I}\right] \mathrm{LSD}$ to $5-\mathrm{HT}_{2}$ receptors in the temporal cortex of the schizophrenic cases and controls indicated that the differences were due to a change in the number of sites $\left(B_{\max } 187 \pm 31 \mathrm{fmols} / \mathrm{mg}\right.$ protein for control; $B_{\max } 252 \pm 37 \mathrm{fmols} / \mathrm{mg}$ protein for schizophrenia; $p<.01$ ) and not in the affinity of the $5-\mathrm{HT}_{2}$ receptors for $\left.{ }^{125} \mathrm{I}\right] \mathrm{LSD}$ binding $(1.3 \pm 0.4$ $\mathrm{nmol} / \mathrm{mg}$ for control, $1.9 \pm 0.6 \mathrm{nmol} / \mathrm{mg}$ for schizophrenia). The suicide cases did not show alterations in the binding of [ $\left.{ }^{125} \mathrm{I}\right] \mathrm{LSD}$ to $5-\mathrm{HT}_{2}$ receptors as compared to controls (Figs. 9 and 10).

\section{DISCUSSION}

\section{Striatum}

The distribution of $5-\mathrm{HT}_{1 \mathrm{~A}}$ and $5-\mathrm{HT}_{2}$ receptors has been well characterized in human brain (Dillon et al. 1991; Hoyer et al. 1986; Pazos et al. 1987a, 1987b; Schotte et al. 1983) and nonhuman primate brain (Lidow et al. 1989). We obtained a $K_{d}$ value for $\left[{ }^{3} \mathrm{H}\right] 8-\mathrm{OH}-\mathrm{DPAT}$ labeling of $5-\mathrm{HT}_{1 \mathrm{~A}}$ receptors that was only slightly lower than values obtained using sections of rat brain (Vergé et al. 1986). Other investigators have also found a lower $K_{d}$ for the binding of $\left[{ }^{3} \mathrm{H}\right] 8-\mathrm{OH}-\mathrm{DPAT}$ to $5-\mathrm{HT}_{1 \mathrm{~A}}$ receptors in sections of rat or human brain than that obtained with membrane preparations (Dillon et al. 1991; Hashimoto et al. 1991). We have also found that the binding of $\left[{ }^{3} \mathrm{H}\right] 8-\mathrm{OH}-\mathrm{DPAT}$ to $5-\mathrm{HT}_{1 \mathrm{~A}}$ receptors in sections of human brain was completely inhibited by guanosine triphosphate (JN Joyce, A Shane and SJ Kim, unpublished findings), in contrast to what was observed in membranes derived from human brain (Hashimoto et al. 1991). This suggests that the linkage to $G$ proteins is functionally intact in tissue sections (De Vivo and Maayani 1990). As expected, we obtained very low binding of $\left[{ }^{3} \mathrm{H}\right] 8-\mathrm{OH}-\mathrm{DPAT}$ to $5-\mathrm{HT}_{1 \mathrm{~A}}$ receptors in the striatal complex (Pazos et al. 1987a). We examined the distribution of the 5- $\mathrm{HT}_{2}$ receptor in tissue sections with $\left[{ }^{3} \mathrm{H}\right]$ ketanserin and $\left[{ }^{125} \mathrm{I}\right] \mathrm{LSD}$. We obtained $\mathrm{K}_{\boldsymbol{d}}$ values for $\left[{ }^{3} \mathrm{H}\right]$ ketanserin binding similar to those reported by Biegon and associates (1986) and Lidow and associates (1989), but lower than that reported by Hoyer and associates (1986). The $K_{d}$ value we determined for [ ${ }^{125}$ I]LSD binding to tissue sections is also similar to that reported by Arango and associates (1990) for human cortical membranes and Engel and associates (1984) for rat cortical membranes. The number of sites labeled with $\left[{ }^{125} \mathrm{I}\right] \mathrm{LSD}$ or $\left[{ }^{3} \mathrm{H}\right]$ ketanserin in the striatum was significantly less than that labeled in the frontal cortex. This is consistent with previous studies that show twoto threefold higher densities in the isocortex than in the basal ganglia and hippocampus (Pazos et al. 1987b; Schotte et al. 1983). We did not find a heterogeneous pattern of $5-\mathrm{HT}_{1 \mathrm{~A}}$ or $5-\mathrm{HT}_{2}$ receptors in the striatum, unlike that for DA receptors (Joyce et al. 1986, 1988, 1991), muscarinic receptors (Lowenstein et al. 1990), and $\beta$-adrenergic receptors (Joyce et al. 1992).

Autoradiographic studies of the distribution of 5-HT uptake studies in human brain have been published using $\left[{ }^{3} \mathrm{H}\right]$ imipramine (Cortés et al. 1988; Gross- 


\section{TEMPORAL CORTEX}
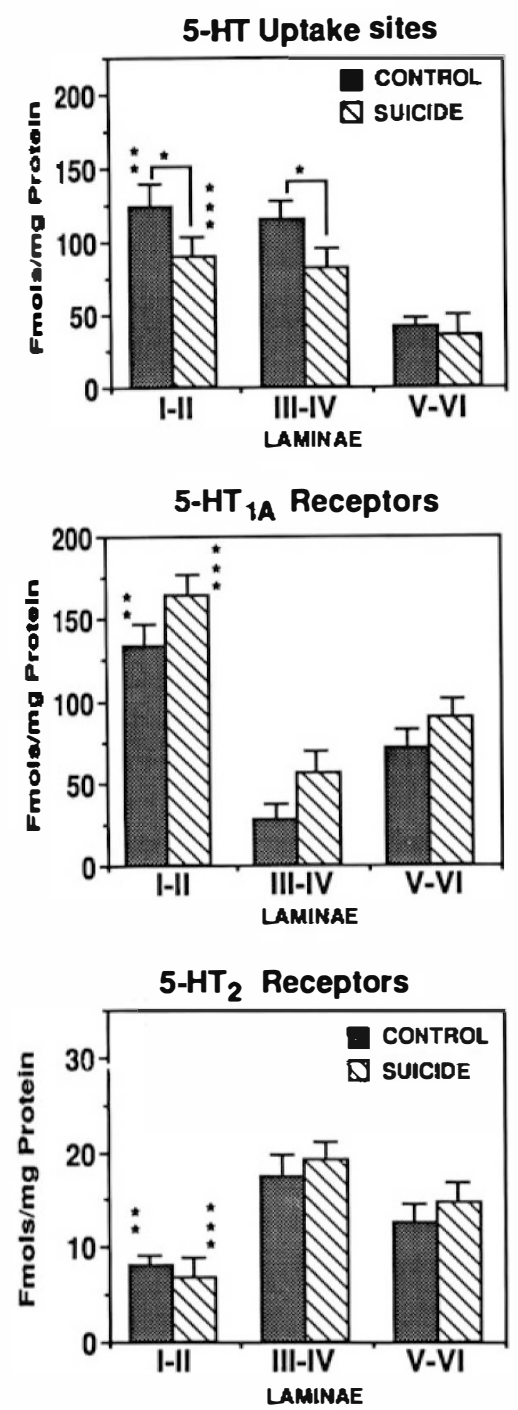

\section{ENTORHINAL CORTEX}
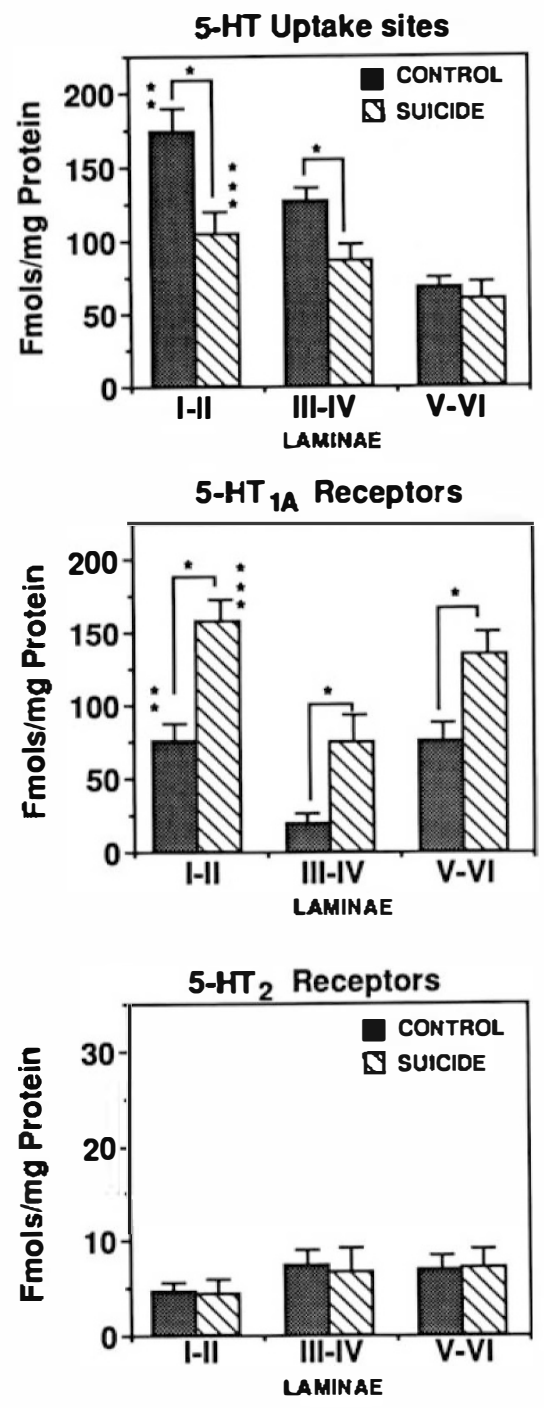

Figure 10. Bar graphs showing the mean number $( \pm S D)$ of 5 -HT uptake sites labeled with $\left[{ }^{3} \mathrm{H}\right] \mathrm{CN}-\mathrm{IMI}(\mathrm{A})$, $5-\mathrm{HT}_{1 \mathrm{~A}}$ receptors labeled with $\left[{ }^{3} \mathrm{H}\right] 8$ OH-DPAT (B), and 5- $\mathrm{HT}_{2}$ receptors labeled with [ $\left.{ }^{125} \mathrm{I}\right] \mathrm{LSD}(\mathrm{C})$ for control and suicide groups for regions of the temporal cortex and entorhinal cortex. The locations of the regions analyzed are shown in Figure 1C. The suicide group showed reduced numbers of 5-HT uptake sites in laminae I-IV of the temporal cortex and entorhinal cortex (between group, $p<.01$ ). The suicide group demonstrated elevated numbers of $5-\mathrm{HT}_{1 \mathrm{~A}}$ receptors in all laminae and entorhinal cortex (between group, $p<$ .001). Within the temporal cortex, the suicide group showed higher numbers of 5-HT uptake sites for laminae I-IV than V-VI (between regions, $p<.01$ ). Serotonin $_{1 \mathrm{~A}}$ receptors were higher in laminae I-II than V-VI, which is greater than laminae III-IV (between regions, $p<.01$ ), and $5-\mathrm{HT}_{2}$ receptors were higher in laminae III-IV than all other laminae $(p<.01)$. Within the entorhinal cortex, the suicide group showed higher numbers of 5-HT uptake sites in laminae I-IV than laminae V-VI (between regions, $p<.01)$. Serotonin $1 \mathrm{~A}$ receptors were lower in laminae III-IV than I-II or $\mathrm{V}-\mathrm{VI}$ (between regions, $p<.01$ ). Between group differences are indicated by single asterisk, significant differences between regions for control group by double asterisk, and significant differences between regions for suicide group by triple asterisk.
Isseroff and Biegon 1988) and [ $\left.{ }^{3} \mathrm{H}\right]$ desmethylimipramine (Gross-Isseroff et al. 1988), but the information provided is limited as the radioligands do not selectively label 5-HT uptake sites ( $\mathrm{D}^{\prime}$ Amato et al. 1987). Only one study has described the autoradiographic distribution of the selective radioligand $\left[{ }^{3} \mathrm{H}\right]$ paroxetine in human brain and the regions utilized were quite limited in scope (Cortés et al. 1988). The radioligand [ $\left.{ }^{3} \mathrm{H}\right] \mathrm{CN}-\mathrm{IMI}$ does selectively label 5-HT uptake sites located on nerve terminals and the cell body (Kovachich et al. 1988) as exemplified by the loss of sites with selective lesions of 5-HT cell bodies (Hensler et al. 1991), and correlation with 5-HT levels and other radioligands that label the5-HT transporter (Kovachich et al. 1988). Our results show that the distribution of $\left[{ }^{3} \mathrm{H}\right] \mathrm{CN}-\mathrm{IMI}$ binding in human brain was highest in the striatal complex, consistent with previous reports of $\left[{ }^{3} \mathrm{H}\right]$ paroxetine binding (Laruelle and Maloteaux 1989; Lawrence et al. 1990).
The autoradiographs showed a heterogeneous pattern in the striatum, with microzones of dense $\left[{ }^{3} \mathrm{H}\right] \mathrm{CN}-\mathrm{IMI}$ bindingevident in the ventral striatum, where the dense microzones were 1.5 to 2 times denser than in the areas surrounding the microzones. These microzones were infrequently observed in the dorsal caudate nucleus and dorsal putamen. This corresponds to what has been observed by 5-HT immunocytochemical demonstration of the serotoninergic innervation of the monkey striatum (Lavoie and Parent 1990). The patchy organization of the serotonin uptake sites is related to an intrinsic neurochemical organization of the striatum, termed the striosomal and matrix compartments, which can be related to heterogeneities in the binding of a number of markers for transmitter systems (Joyce et al. 1988, 1992).

We observed significant changes in the pre- and postsynaptic components of the 5-HT system in the 
schizophrenic striatum. A large increase in the number of 5-HT uptake sites was observed in all regions of the striatum and two striking changes were observed: (1) an increase in the number and density of patches in the ventral striatum, and (2) the appearance of patches of dense binding in the dorsal putamen and caudate nucleus. Since we used a concentration of $\left[{ }^{3} \mathrm{H}\right] \mathrm{CN}$-IMI approximately three times the $\mathrm{K}_{\mathrm{d}}$ (as determined in control tissue), it was unlikely that the changes observed in the schizophrenic cases were due to changes in the affınity of the radioligand for the uptake sites. The change in the number of uptake sites is consistent with previous evidence that there was an increase in the concentrations of 5-HT and/or 5-HIAA in the putamen of schizophrenic cases (Crow et al. 1979; Farley et al. 1980; Korpi et al. 1986). Consequently, there may exist a hyperinnervation of schizophrenic striatum by 5 -HT afferents including aberrant innervation to the dorsal caudate.

We also observed a substantial increase in the number of $5-\mathrm{HT}_{2}$ receptors in the schizophrenic cases, but the increases were not in the same regions as those for the 5-HT uptake sites. The ventral putamen and nucleus accumbens showed significant increases not observed in the dorsal striatum. The increase in the number of $5-\mathrm{HT}_{2}$ receptors was evident with both $\left[{ }^{3} \mathrm{H}\right]$ ketanserin and with [ $\left.{ }^{125} \mathrm{I}\right] \mathrm{LSD}$ binding. Moreover, there was no evidence that the affinity of [ ${ }^{125}$ I]LSD for $5-\mathrm{HT}_{2}$ receptors differed between the control and schizophrenic cases, indicating that there was a better than 1.8-fold increase in the number of receptors in the schizophrenia group. This report differs from previous reports of no difference between schizophrenic and control groups for the number of $5-\mathrm{HT}_{2}$ receptors in the caudate-putamen (Owen et al. 1981) or nucleus accumbens (Mackay et al. 1978). Direct comparison of our results with those of previous studies is difficult, as nonselective radioligands were used, and the regions examined may not be comparable to those used in this autoradiographic study. In contrast to our results for $5-\mathrm{HT}_{2}$ receptors in the schizophrenic group, no change in the number of $5-\mathrm{HT}_{1 \mathrm{~A}}$ receptors was observed in the striatum. We have previously observed in schizophrenic cases that the dorsal caudate nucleus shows a reduction in the number of DA uptake sites (Joyce et al. 1988) and an increase in the number of $\beta_{1}$ adrenergic receptors (Joyce et al. 1992). The dorsal striatum also evidenced an increase in patches of binding for $\left[{ }^{3} \mathrm{H}\right] \mathrm{CN}$-IMI binding to 5 -HT uptake sites. The ventral striatum displays an increase in $5-\mathrm{HT}_{2}$ receptors, $5-\mathrm{HT}$ uptake sites, an increase in DA D2 receptors (Joyce et al. 1988), and $\beta_{1}$-adrenergic receptors (Joyce et al. 1992). The results of this and previous studies (Joyce et al. 1988, 1992) suggest that the compartmental organization of the monoamine systems may be altered in schizophrenic cases. It will be important to determine whether the differences between the schizophrenicand control groups in the striatal organization of the DA system, 5-HT system, and noradrenergic system reflect a generalized disturbance in the boundaries of the striosomal and matrix compartments.

\section{Cortex and Hippocampus}

Previous studies have demonstrated that the $5-\mathrm{H} \Gamma_{1 \mathrm{~A}}$ receptor represents the major member of the $5-\mathrm{HT}_{1}$ family in all cortical regions and in the hippocampus (Dillon et al. 1991; Pazos et al. 1987a). In the cortex, the $5-\mathrm{HT}_{1 \mathrm{~A}}$ receptor shows a different pattern from the $5-\mathrm{HT}_{2}$ receptor with the $5-\mathrm{HT}_{1 \mathrm{~A}}$ receptor highest in the external laminae and the $5-\mathrm{HT}_{2}$ receptor higher in the internal laminae (Dillon et al. 1991; Lidow et al. 1989; Pazos et al. 1987a, 1987b). Consistent with those data, we found that in most cortical regions the binding of $\left[{ }^{3} \mathrm{H}\right] 8-\mathrm{OH}-\mathrm{DPAT}$ to $5-\mathrm{HT}_{1 \mathrm{~A}}$ receptors was better than threefold higher in laminae I and II than laminae III-VI. Using [ ${ }^{125} \mathrm{I}$ ]LSD to label $5-\mathrm{HT}_{2}$ receptors, we found higher binding in the intermediate laminae $(40 \%$ to $100 \%$ higher numbers) than external or deep laminae of frontal, occipital, parietal, and temporal cortices. This pattern was consistent across cortical regions except for the cingulate cortex, which showed equivalent binding in laminae III and IV, and the motor cortex, which showed a very indistinct laminar organization. We found that $\left[{ }^{3} \mathrm{H}\right]$ ketanserin binding exhibited a less substantial laminar appearance than [ $\left.{ }^{125} \mathrm{I}\right] \mathrm{LSD}$ binding, but Beigon and associates (1986) have reported that $\left[{ }^{3} \mathrm{H}\right]$ ketanserin binding is higher in laminae IV than other laminae of the frontal cortex of humans. Moreover, a recent study by Arango and associates (1990) also indicated that [125I]LSD-labeled sites show the highest binding in the intermediate layers of the frontal cortex. The higher degree of laminar organization observed with [ $\left.{ }^{125} \mathrm{I}\right] \mathrm{LSD}$ than $\left[{ }^{3} \mathrm{H}\right]$ ketanserin may reflect differences in the quenching properties of ${ }^{3} \mathrm{H}$-radioligands as compared to ${ }^{125}$ I-radioligands in cortex (Lidow et al. 1988).

The pattern of $5-\mathrm{HT}_{1 \mathrm{~A}}$ receptors that were sampled differed in the temporal cortex (superior, middle, and inferior gyri) as compared to the frontal cortex. We determined that the number of $5-\mathrm{HT}_{1 \mathrm{~A}}$ receptors was more than threefold higher in the upper and deep laminae than in the middle laminae (see also, Dillon et al. 1991). Previous reports have also indicated that the entorhinal cortex shows a highly laminated pattern of $5-\mathrm{HT}_{1 \mathrm{~A}}$ receptor expression with layers I-II and V higher than III or VI. We found this also to be the case, although we observed almost similar levels of binding in the deep and upper laminae. We observed that $5-\mathrm{HT}_{2}$ receptors labeled with [ ${ }^{125} \mathrm{I}$ ]LSD were signifcantly lower in number in the entorhinal cortex than 
the isocortex or hippocampus. The binding in the entorhinal cortex was denser in laminae III and IV than the other laminae. This contrasts with the region immediately adjacent to the entorhinal cortex, the perirhinal cortex of the lateral occipitotemporal gyrus, which does show signifıcantly higher binding than the entorhinal cortex. Similar findings were found by Grosslsseroff and associates (1990) using the compound $\left[{ }^{3} \mathrm{H}\right]$ ketanserin to label $5-\mathrm{HT}_{2}$ sites.

Our results regarding the distribution of $5-\mathrm{HT}_{1 \mathrm{~A}}$ and $5-\mathrm{HT}_{2}$ receptors in the hippocampus extend previous findings by directly examining differences in expression between the rostral and the midbody of the hippocampus. It has been reported that in the hippocampus, $5-\mathrm{HT}_{1 \mathrm{~A}}$ receptors were densest over the pyramidal layers of $C A_{1}-C A_{2}$, low to $C A_{3}$, and high in the molecular layer of DG (Dillon et al. 1991; Pazos et al. 1987a). We also observed that the $\mathrm{CA}_{1}$ subfield showed the highest binding in the hippocampus and the $\mathrm{CA}_{2}$ subfield appeared lighter than the $\mathrm{CA}_{1}$ subfeld in most cases. We did not observe dense binding in the molecular layer of the DG in either the midbody or rostral portion of the hippocampus. The differences in the reported pattern of binding of $\left[{ }^{3} \mathrm{H}\right] 8-\mathrm{OH}-\mathrm{DPAT}$ to $5-\mathrm{HT}_{1 \mathrm{~A}}$ receptors in the DG with this study and previous studies cannot be attributed to differences in the incubation conditions as similar methodologies were utilized. We determined that the binding of [ $\mathrm{H}] 8-\mathrm{OH}-\mathrm{DPAT}$ to $5-\mathrm{HT}_{1 \mathrm{~A}}$ receptors was greatest in the rostral hippocampus and differentiation between subfields was more difficult in this region than in the midbody of the hippocampus. This difficulty in differentiating subfields in the rostral hippocampus might contribute to the variability in the reports. This issue is also relevant to the studies of $5-\mathrm{HT}_{2}$ receptors in hippocampus which have been reported to be higher in number in the $\mathrm{CA}_{1}-\mathrm{CA}_{3}$ subfields and DG than in the subiculum, but significantly lower than the isocortex (Hoyer et al. 1986; Pazos et al. 1987b). We found a more clearly differentiated pattern of expression using $\left.\left[{ }^{25}\right]\right] \mathrm{LSD}$ to label $5-\mathrm{HT}_{2}$ receptors, with differences in the number of $5-\mathrm{HT}_{2}$ receptors in the rostral as compared to the midbody of the hippocampus. The number of $5-\mathrm{HT}_{2}$ receptors was found to be quite low for all subfields rostrally, particularly the subiculum and $\mathrm{CA}_{1}$, but reasonably high in the midbody of the hippocampus. In the midbody of the hippocampus, the subiculum and $\mathrm{CA}_{1}$ subfields exhibited the highest number of receptors, and the $\mathrm{CA}_{3}$ and DG the lowest number. The differences between our study and others describing the pattern of $5-\mathrm{HT}_{2}$ receptors do not appear to reflect different pharmacologic properties of [ ${ }^{25 I}$ I]LSD binding as compared to $\left[{ }^{3} \mathrm{H}\right]$ ketanserin; our preliminary studies did not indicate [ ${ }^{125}$ I]LSD-labeled sites in cortex and hippocampus that $\left[{ }^{3} \mathrm{H}\right]$ ketanserin did not recognize. There was one exception, in the mo- lecular layer of the DG and moleculare radiatum of the $\mathrm{CA}_{1}$ of the hippocampus, the binding of $\left[{ }^{125} \mathrm{I}\right] \mathrm{LSD}$ was not displaced by ketanserin, and there was no significant $\left[{ }^{3} \mathrm{H}\right]$ ketanserin binding. However, the nonselective properties of $\left[{ }^{3} \mathrm{H}\right]$ ketanserin (Hoyer et al. 1987; Leysen et al. 1987, 1988) could contribute to the different findings. Although $\left[{ }^{3} \mathrm{H}\right]$ ketanserin has been the preferred radioligand for the study of $5-\mathrm{HT}_{2}$ receptors, it is known to label the monoamine transporter located on synaptic vesicles (Leysen et al. 1987, 1988) and $\alpha_{1}$-adrenergic receptors (Hoyer et al. 1987), as well as the $5-\mathrm{HT}_{2}$ receptor, and may not be the most suitable radioligand for visualizing $5-\mathrm{HT}_{2}$ receptors. Our findings would argue for an almost complementary organization of $5-\mathrm{HT}_{1 \mathrm{~A}}$ receptors and $5-\mathrm{HT}_{2}$ receptors in isocortex, particularly in the temporal lobe and in the rostral hippocampus.

Previous reports of the autoradiographic pattern of $\left[{ }^{3} \mathrm{H}\right]$ imipramine (Gross-Isseroff and Biegon 1988), $\left[{ }^{3} \mathrm{H}\right]$ desmethylimipramine (Gross-Isseroff et al. 1988), and $\left[{ }^{3} \mathrm{H}\right]$ paroxetine (Cortés et al. 1988) binding to 5-HT uptake sites in human cortex did not demonstrate a strong laminar pattern and only small differences in density between cortical regions were observed. The pattern of 5-HT uptake sites in cortex labeled with $\left[{ }^{3} \mathrm{H}\right]$ imipramine was shown to be somewhat denser in the internal as compared to the external laminae in one autoradiography study (Cortés et al. 1988). In contrast, we found that the pattern of binding of $\left[{ }^{3} \mathrm{H}\right] \mathrm{CN}-\mathrm{IMI}$ to 5-HT uptake sites was highest in the upper laminae, somewhat lower in the middle laminae, and lowest in the deep laminae. The different results may reflect the binding of $\left[{ }^{3} \mathrm{H}\right]$ imipramine and $\left[{ }^{3} \mathrm{H}\right]$ desmethylimipramine to sites not associated with the 5-HT uptake site (D'Amato et al. 1987). However, in the primate cortex, the density of 5-HT immunoreactive fibers was observed to be relatively similar across all laminae with small variations in patterning. In frontal cortex there were slightly higher densities in layer I, but in motor and parietal cortex, the fibers were denser in the supragranular layers (Tork 1990; Wilson and Molliver 1991). Our observations on the pattern of 5-HT uptake sites in the hippocampus, relatively high in the entorhinal cortex and DG, lower in $\mathrm{CA}_{3}$, and lowest in the $\mathrm{CA}_{1}$ subfields of the hippocampus, are consistent with immunocytochemical studies of the patterning of 5-HT axons (Amaral and Campbell 1986; Tork 1990). Our findings are also consistent with the previous autoradiographic studies of the labeling of 5-HT uptake sites with $\left[{ }^{3} \mathrm{H}\right]$ imipramine by Biegon and associates (GrossIsseroff and Biegon 1988) but differ from the findings of Cortés and associates (1988). Consequently, the pattern of distribution of $\left[{ }^{3} \mathrm{H}\right] \mathrm{CN}$-IMI binding to 5-HT uptake sites may not perfectly correlate with the distribution of 5-HT fibers in the cortex but appeared to be highly correlated in the medial temporal lobe (and stri- 
atum, see above). The distribution of $\left[{ }^{3} \mathrm{H}\right] \mathrm{CN}-\mathrm{IMI}$ binding to the 5-HT uptake sites appeared to match the combined distributions of the $5-\mathrm{HT}_{1 \mathrm{~A}}$ receptor and the $5-\mathrm{HT}_{2}$ receptor in the frontal cortex. In the temporal lobe, the superior, middle, and inferior gyri showed a less obvious overlap. In the entorhinal cortex, the pattern of 5-HT $1 \mathrm{~A}$ receptors and 5-HT uptake sites contrasted with the low density of $5-\mathrm{HT}_{2}$ receptors. In the hippocampus there was a contrasting pattern of 5-HT uptake sites, $5-\mathrm{HT}_{1 \mathrm{~A}}$ receptors, and $5-\mathrm{HT}_{2}$ receptors.

\section{Alterations in Schizophrenia}

In contrast to what we found in the striatum, the number of 5-HT uptake sites was not increased in any cortical region of the schizophrenic group. There was, in fact, a marked reduction of sites in the external and middle laminae of the anterior cingulate cortex, frontal cortex, and posterior cingulate cortex but not in the motor cortex, temporal cortex, or hippocampus. One group found reduced numbers of $\left[{ }^{3} \mathrm{H}\right]$ imipramine sites in the frontal cortex of the right hemisphere of schizophrenics as compared to controls, but no differences for the left hemisphere (Demeter et al. 1989). In a published abstract, Laruelle and associates (1990) reported a reduction in $\left[{ }^{3} \mathrm{H}\right]$ paroxetine binding to frontal cortex in postmortem brains of schizophrenics. There have been no studies that have reported changes in the levels of 5-HT in the frontal cortex or any other cortical region (Crow et al. 1979; Joseph et al. 1979; Korpi et al. 1986; Winblad et al . 1979). In both previous studies using radioligands to label5-HT uptake sites, it was found that patients with a diagnosis of depression (Demeter et al. 1989) or who had committed suicide (Laruelle et al. 1990) also had reductions in the number of sites that were similar in magnitude to the schizophrenic cases. This raises the possibility that the changes in the number of 5-HT uptake sites found in this study for the anterior cingulate cortex, frontal cortex, parietal cortex, and posterior cingulate cortex cannot be attributed to schizophrenia per se, but would be common to many psychiatric illnesses that have an affective component (Crow et al. 1984; Gross-Isseroff et al. 1989; Stanley et al. 1982; Zubenko et al. 1991). However, other groups have not found any changes in $\left[{ }^{3} \mathrm{H}\right]$ imipramine (GrossIsseroff et al . 1989), [ $\left.{ }^{3} \mathrm{H}\right]$ desmethylimipramine (GrossIsseroff et al . 1988), or [ $\left.{ }^{3} \mathrm{H}\right]$ paroxetine (Lawrence et al. 1990) binding in suicide cases for brain regions that we determined were altered in the schizophrenia group (striatum, frontal, cortex, or cingulate cortex). Consequently, it will be important to examine the specificity of the changes in 5-HT uptake sites in schizophrenia and other disorders with an affective component in further studies.

In the same schizophrenic group, $5-\mathrm{HT}_{2}$ receptors were substantially elevated in the posterior cingulate (middle laminae), temporal cortex (middle laminae), and hippocampus but not altered in the frontal, anterior cingulate, or motor cortices. Previous studies (Aroraand Meltzer 1991; Mita et al. 1986) reported finding a decrease in $\left[{ }^{3} \mathrm{H}\right]$ spiroperidol or $\left[{ }^{3} \mathrm{H}\right]$ ketanserin binding to $5-\mathrm{HT}_{2}$ receptors in the frontal cortex of schizophrenics as compared to controls. They attributed the results to a reduction in the maximum number of $5-\mathrm{HT}_{2}$ sites and not to a change in the affinity of the compounds for the $5-\mathrm{HT}_{2}$ sites. It is unclear if these discrepant results reflect the utilization of different radioligands, different groups of patients, methods of tissue preparation (membrane binding versus autoradiographic methods), or even region of the brain. The region designated as frontal cortex in this study did not include the frontal pole, which was included in the previous studies. Additionally, there were a number of reports that suicide is related to an elevation in $5-\mathrm{HT}_{2}$ receptors in the frontal cortex (Arango et al. 1990; Mann et al. 1986; McKeith et al. 1987; Arora and Meltzer 1989a). Some of our schizophrenic cases had committed suicide, and this may have contributed to variability in the results of $5-\mathrm{HT}_{2}$ receptor measurement in frontal cortex.

We found elevations in several regions of the postcentral cortex, including the posterior cingulate (middle laminae), temporal cortex (middle laminae), and hippocampus. However, in the medial temporal lobe the entorhinal cortex was not affected. An examination of $5-\mathrm{HT}_{2}$ receptor expression in schizophrenia for regions outside the frontal cortex has not been previously reported. The alterations in $5-\mathrm{HT}_{2}$ receptor density that we observed were unlikely to be due to antipsychotic medication, age, or cause of death. Chronic administration of classic antipsychotics, such as haloperidol, has been shown not to modify (O'Dell et al. 1990; Wilmot and Szczepanik 1989), or even decrease (Lee and Tang 1984; Andree et al. 1986), the number of $5-\mathrm{HT}_{2}$ receptors in frontal cortex of rats. In fact, increases in the density of $5-\mathrm{HT}_{2}$ receptors could not be induced by any method that reduced 5-HT transmission or with chronic treatment with antidepressant drugs (for review, Frazer et al. 1988). Gross-Isseroff and associates (1990) have reported that $5-\mathrm{HT}_{2}$ receptor density was affected somewhat by age, but in a region specific manner. Receptor number was decreased in the frontal cortex and hippocampus and not other cortical or subcortical regions of elderly as compared to young patients. Since the group of schizophrenics that were utilized in this study contained a number of cases that were younger than the control cases and had committed suicide, there was the potential concern that the observed changes might be related to age. Additionally, there were a number of reports that suicide is related to an elevation in $5-\mathrm{HT}_{2}$ receptors in the frontal cortex (Arango et al. 1990; Mann et al. 1986; McKeith et al. 1987; Arora and Meltzer 1989a). Therefore, we exam- 
ined the 5-HT system in the parietal cortex and temporal cortex of a group of cases that had committed suicide, did not have a diagnosis of schizophrenia, and were of a younger age than the control group. Some differences from controls were apparent, but these were not regionally the same as found in the schizophrenic group. No change in the pattern or number of $5-\mathrm{HT}_{2}$ sites was observed in the temporal cortex (or hippocampus) of suicide cases as compared to controls. This latter finding was in agreement with the recent autoradiographic study by Arango and associates (1990) that found increases in $5-\mathrm{HT}_{2}$ receptors in the frontal cortex, but not the temporal cortex of suicide cases.

We observed increased numbers of $5-\mathrm{HT}_{1 \mathrm{~A}}$ receptors in those brain regions of schizophrenics that did not show changes in the number of 5-HT uptake sites, including the posterior cingulate and the motor cortex. We also observed increased numbers of $5-\mathrm{HT}_{1 \mathrm{~A}}$ receptors in the hippocampus, but not the entorhinal cortex. For several reasons, we believe these changes in $5-\mathrm{HT}_{1 \mathrm{~A}}$ receptors in the hippocampus to be disease specific. First, there was no significant overlap of the regions showing increases in $5-\mathrm{HT}_{1 \mathrm{~A}}$ and $5-\mathrm{HT}_{2}$ receptor numbers; thus, there is regional selectivity in the receptor alterations in schizophrenia. Second, although the increase in number of $5-\mathrm{HT}_{1 \mathrm{~A}}$ receptors in the hippocampus of the schizophrenics was also observed in the suicide cases, the subfields affected were not the same in the schizophrenic and suicide cases. The increase in $5-\mathrm{HT}_{1 \mathrm{~A}}$ receptors was significant for the DG of the schizophrenic group and for the $\mathrm{CA}_{1}-\mathrm{CA}_{3}$ subfields of the suicide group. Biegon and associates (Dillon et al. 1991) have also explored whether $5-\mathrm{HT}_{1 \mathrm{~A}}$ receptor number was altered in suicide cases. Although they observed a tendency for an increase in number in the hippocampus, the only significant findings related to those cases were that ethanol consumption was high. Consequently, the changes in $5-\mathrm{HT}_{1 \mathrm{~A}}$ receptor numbers associated with schizophrenia are likely to be different from suicide processes. In contrast to other regions of the brain, $5-\mathrm{HT}_{1 \mathrm{~A}}$ receptors in the hippocampus could be modified by lesions to the 5-HT system and by chronic administration of some antidepressant drugs (Hensler et al. 1991). Serotonin ${ }_{1 A}$ receptors are thought to be located on cells postsynaptic to the terminals in cortical regions and in the hippocampus (Gozlan et al. 1983; Hall et al. 1985). Administration of tranylcypromine, but not other antidepressant drugs, can increase the number of receptors in the $\mathrm{CA}_{2}-\mathrm{CA}_{3}$ subfields of the hippocampus but not in cortical regions (Hensler etal. 1991). Whereas some patients in the suicide group had taken antidepressants, there was no evidence that the schizophrenic patients were taking antidepressants or alcohol. Additionally, we did not find a reduction in 5-HT uptake sites in the regions of the cortex and hippocampus where elevations in $5-\mathrm{HT}_{1 \mathrm{~A}}$ receptors were found. Consequently, the increase in $5-\mathrm{HT}_{1 \mathrm{~A}}$ receptors in the DG of the schizophrenic cases was unlikely to be due to drug treatment, response to reduced 5-HT, or inclusion of schizophrenic cases that committed suicide. However, caution must be used in interpreting these findings; Winblad and associates (1979) have found a reduced 5-HT content in hippocampus of schizophrenic cases. One group has also recently reported that an increase in $5-\mathrm{HT}_{1 \mathrm{~A}}$ receptor number could be found in the prefrontal cortex and temporal lobe but not in the hippocampus of elderly schizophrenic cases (Hashimoto et al. 1991). The study utilized membranes derived from these regions of brain and so may not be directly comparable to our study. Our data show that $5-\mathrm{HT}_{1 \mathrm{~A}}$ receptors were affected differently from 5- $\mathrm{HT}_{2}$ receptors in the schizophrenic group and support the view that the elevation in 5-HT receptors in a number of cortical regions was an important finding.

\section{SUMMARY}

Our results suggest that in schizophrenia, there are selective changes in the 5 -HT system in structures that compose the limbic system including the cortex, hippocampus, and striatum. These data support the hypothesis that the 5-HT system plays a role in schizophrenia (Bleich et al. 1988; Meltzer 1989). Our results show that more than one component of the 5-HT systems is directly altered in schizophrenia, with increased 5-HT receptor number in several limbic regions. A supersensitive 5 -HT system in schizophrenia is suggested by the evidence that compounds with antiserotonergic properties have antipsychotic properties (Castelaoo et al. 1989; Meltzer et al. 1989; Vinar et al. 1989). More recently, Iqbal and associates (1991) examined the response of schizophrenic patients to direct challenge with a 5-HT agonist and found marked worsening of symptoms, also suggestive of a supersensitive 5-HT system. Chronic treatment with many of the atypical antipsychotics can reduce the number of $5-\mathrm{HT}_{2}$ receptors (Leysen et al. 1987b; O'Dell et al. 1990; Wilmot and Szczepanik 1989). It will be important to determine if modification of receptor number in limbic cortex and limbic regions of striatum may be a means by which these drugs can interfere in the development of psychotic symptoms.

\section{ACKNOWLEDGMENTS}

This research was supported by U.S. Public Health Service Grants MH 43852 and MH 43880, A G 09215 to J.N. Joyce; Research Scientist Award MH 00044, R01NS 19597, and DRSG2S07-PR-05415-26 to A. Winokur; and National Institutes of Health Grant MH 31862 to Dr. Bird (McLean Hospital, Belmont, MA) for the Brain Tissue Resource Center. 


\section{REFERENCES}

Amaral DG, Campbell MJ (1986): Transmitter systems in the primate dentate gyrus. Human Neurobiol 5:169-180

Amaral DG, Insausti R (1990): Hippocampal formation. In Paxinos G (ed), The Human Nervous System. New York, Academic Press, pp 711-755

Andree TH, Mikuni M, Tong CY, Koenig JI, Meltzer HY (1986): Differential effect of subchronic treatment with various neuroleptic agents on serotonin 2 receptors in rat cerebral cortex. J Neurochem 46:191-197

Arango V, Ernsberger P, Marzuk PM, Chen H-S, Tierney H, Stanley M, Reis DJ, Mann JJ (1990): Autoradiographic demonstration of increased serotonin $5-\mathrm{HT}_{2}$ and $\beta$-adrenergic receptor binding sites in the brain of suicide victims. Arch Gen Psychiatry 47:1038-1047

Arora RC, Meltzer HY (1989a): Serotonergic measures in the brains of suicide victims: $5-\mathrm{HT}_{2}$ binding sites in the frontal cortex of suicide victims and control subjects. Am J Psychiatry 146:730-736

Arora RC, Meltzer HY (1989b): ${ }^{3} \mathrm{H}$-imipramine binding in the frontal cortex of suicides. Psychiatry Res 30:125-135

Arora RC, Meltzer HY (1991): Serotonin 2 (5-HT2) receptor binding in the frontal cortex of schizophrenic patients. Am J Psychiatry 146:730-736

Artymyshyn R, Smith A, Wolfe BB (1990): The use of ${ }^{3} \mathrm{H}$ standards in ${ }^{125} \mathrm{I}$ autoradiography. J Neurosci Method 32:185-192

Bennett JP, Enna SJ, Bylund DB, Gillin JC, Wyatt RJ, Snyder SH (1979): Neurotransmitter receptor in frontal cortex of schizophrenics. Arch Gen Psychiatry 36:927-934

Biegon A, Kargman S, Snyder L, McEwen BS (1986): Characterization and localization of serotonin receptors in human brain postmortem. Brain Res 363:91-98

Bleich A, Brown S-L, Kahn R, van Praag HM (1988): The role of serotonin in schizophrenia. Schizophrenia Bull 14:287-315

Castelaoo JF, Ferreira L, Gelder YG, Heylen SL (1989): The efficacy of the D2 and 5-HT2 antagonist risperidone (R $64,766)$ in the treatment of chronic psychosis. An open dose-finding study. Schizophrenia Res 2:411-415

Cortés R, Soriano E, Pazos A, Probst A, Palacios JM (1988): Autoradiography of antidepressant binding sites in the human brain: localization using $\left[{ }^{3} \mathrm{H}\right]$ imipramine and $\left[{ }^{3} \mathrm{H}\right]$ paroxetine. Neuroscience 27:473-496

Crow TJ, Baker H, Gross A, Joseph M, Lofthouse R, Longden A, Owen F, Riley G, Glover V, Killpack W (1979): Monoamine mechanisms in chronic schizophrenia: Postmortem neurochemical findings. B J Psychiatry 134: 249-256

Crow TJ, Cross AJ, Cooper SJ, Deakin JFW, Ferrier IN, Johnson JA, Joseph $\mathrm{MH}$, Owen F, Poulter M, Lofthouse R, Corsellis JAN, Chambers DR, Blessed G, Perry EK, Perry RH, Tomlinson BE (1984): Neurotransmitter receptors and monoamine metabolites in brains of patients with Alzheimer-type dementia and depression, and suicides. Neuropharmacology 23:1561-1569

D'Amato RJ, Largent BL, Snowman AM, Snyder SH (1987): Selective labeling of serotonin uptake sites in rat brain by $\left[{ }^{3} \mathrm{H}\right]$ citalopram contrasted to the labeling of multiple sites by $\left[{ }^{3} \mathrm{H}\right]$ imipramine. J Pharmacol Exp Ther 242: 364-371

Demeter E, Tekes K, Majorossy K, Palkovits M, Soós M, Magyar K, Somogy E (1989): The asymmetry of ${ }^{3} \mathrm{H}$-imipramine binding may predict psychiatric illness. Life So 44:1403-1410

De Vivo M, Maayani S (1990): Stimulation and inhibition of adenylyl cyclase by district 5-hydroxytryptamine receptors. Biochem Pharmacol 40:1551-1558

Dillon KA, Gross-Isseroff R, Israeli M, Biegon A (1991): Autoradiographic analysis of serotonin $5-\mathrm{HT}_{1 \mathrm{~A}}$ receptor binding in the human brain postmortem: effects of age and alcohol. Brain Res 554:56-64

Engel G, Muller-Schweinitzer E, Palacios JM (1984): [125Iodo]LSD, a new ligand for the characterisation and localization of $5-\mathrm{HT}_{2}$ receptors. Naunyn Schmiedebergs Arch Pharmacol 325:328-336

Farley I, Shannak K, Hornykiewicz O (1980): Brain monoamine changes in chronic paranoid schizophrenia and their possible relation to increased dopamine receptor sensitivity. In Pepeu G, Kuhar M, Enna S (eds), Receptors for Neurotransmitters and Peptide Hormones. New York, Raven Press, pp 427-433

Frazer A, Offord SJ, Lucki I (1988): Regulation of serotonin receptors and responsiveness in the brain. In SandersBush E (ed), The Serotonin Receptors. Clifton, NJ, Humana Press, pp 319-362

Frazer A, Maayani S, Wolfe BB (1990): Subtypes of receptors for serotonin. Annu Rev Pharmacol Toxicol 30:307-348

Gozlan H, El Mestikawy S, Pichat L, Glowinski J, Hamon M (1983): Identification of presynaptic serotonin autoreceptors using a new ligand: ${ }^{3} \mathrm{H}$-DPAT. Nature 305:140-142

Gross-Isseroff R, Biegon A (1988): Autoradiographic analysis of $\left[{ }^{3} \mathrm{H}\right]$ imipramine binding in the human brain postmortem: effects of age and alcohol. J Neurochem 51: 528-534

Gross-Isseroff R, Israeli M, Biegon A (1988): Autoradiographic analysis of $\left[{ }^{3} \mathrm{H}\right]$ desmethyl-imipramine binding in the human brain postmortem. Brain Res 456:120-126

Gross-Isseroff R, Israeli M, Biegon A (1989): Autoradiographic analysis of tritiated imipramine binding in the human brain post mortem: effects of suicide. Arch Gen Psychiatry $46: 237-241$

Gross-Isseroff R, Salama D, Israeli M, Biegon A (1990): Autoradiographic analysis of age-dependent changes in serotonin 5- $\mathrm{HT}_{2}$ receptors of the human brain postmortem. Brain Res 519:223-227

Hall MD, El Mestikawy S, Emerit MB, Pichat L, Hamon M,

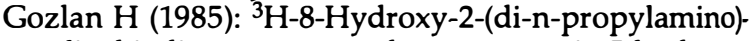
tetralin binding to pre- and post-synaptic 5-hydroxytryptamine binding sites in various regions of the rat brain. J Neurochem 44:1685-1696

Hashimoto T, Nishino N, Nakai H, Tanka C (1991): Increase in serotonin $5-\mathrm{HT}_{1 \mathrm{~A}}$ receptors in prefrontal and temporal cortices of brains from patients with chronic schizophrenia. Life Sci 48:355-363

Hensler JG, Kovachich GB, Frazer A (1991): A quantitative autoradiographic study of serotonin $1 \mathrm{~A}$ receptor regulation. Effect of 5,7-dihydroxytryptamine and antidepressant treatments. Neuropsychopharmacology 4:131-144 
Hoyer D, Pazos A, Probst A, Palacios JM (1986): Serotonin receptors in the human brain. II. Characterization and autoradiographic localization of $5-\mathrm{HT}_{1 \mathrm{C}}$ and $5-\mathrm{HT}_{2}$ recognition sites. Brain Res 376:97-107

Hoyer D, Vos P, Closse A, Palacios JM, Engel G, Daveirs H (1987): ${ }^{3} \mathrm{H}$-ketanserin labels serotonin $5-\mathrm{HT}_{2}$ and $\alpha_{1}$ adrenergic receptor in human brain cortex. J Cardiovasc Pharmacol 10 [Suppl 3]:S48-S50

\qbal N, Asnis GM, Wetzler S, Kay SR, van Praag HM (1991): The role of serotonin in schizophrenia new findings. Schizophrenia Res 5:181-182

Joseph MH, Baker HF, Crow TJ, Riley GJ, Rigsby D (1979): Brain tryptophan metabolism in schizophrenia: A postmortem study of metabolites on the serotonin and kynurenine pathways in schizophrenic and control subjects. Psychopharmacology 62:279-285

JoyceJN, Sapp DW, Marshall JF (1986): Human striatal dopamine receptors are organized in compartments. Proc Natl Acad Sci USA 83:8002-8006

Joyce JN, Lexow N, Bird E, Winokur A (1988): Organization of dopamine D1 and D2 receptors in human striatum: Receptor autoradiographic studies in Huntington's disease and schizophrenia. Synapse 2:546-557

JoyceJN, Janowski A, Neve KA (1991): Characterization and distribution of [ $\left.{ }^{125} \mathrm{I}\right]$ Epidepride binding to dopamine D2 receptors in basal ganglia and cortex of human brain. J Pharmacol Exp Ther 253:1253-1263

Joyce JN, Lexow N, Kim SJ, Artymyshyn R, Cassanova M, Keinman J, Bird E, Winokur A (1992): Distribution of beta-adrenergic receptor subtypes in human post-mortem brain: alterations in limbic regions of schizophrenics. Synapse 10:228-246

Korpi ER, Kleinman JE, Goodman SI, Phillips I, DeLisi LE, Linnoila M, Wyatt RJ (1986): Serotonin and 5-hydroxyindoleacetic acid in the brains of suicide victims: Comparison in chronic schizophrenic patients with suicide as cause of death. Arch Gen Psychiatry 43:594-600

Kovachich GB, Aronson CE, Brunswick DJ, Frazer A (1988): Quantitative autoradiography of serotonin uptake sites in rat brain $\left[{ }^{3} \mathrm{H}\right]$ cynaoimipramine. Brain Res 454:78-88

Lanuelle M, Maloteaux JM (1989): Regional distribution of serotonergic pre- and postsynaptic markers in human brain. Acta Psychiatr Scand Suppl 350:56-59

Laruelle M, Casanova F, Weinberger DR, Kleinman JE (1990): $\left[{ }^{3} \mathrm{H}\right]$ paroxetine binding in postmortem brains of schizophrenic, suicides, cocaine addicts and controls. Soc Neurosci Abstr 16:1350

Lvoie B, Parent A (1990): Immunohistochemical study of the serotoninergic innovation of the basal ganglia in the squirrel monkey. J Comp Neurol 299:1-16

Lawrence KM, De Paermentier F, Cheetham SC, Crompton MR, Katona CL, Horton RW (1990): Brain 5-HT uptake sites, labelled with $\left[{ }^{3} \mathrm{H}\right]$ paroxetine, in antidepressantfree depressed suicides. Brain Res 526:17-22

LeeT, Tang SW (1984): Loxapine and clozapine decrease serotonin $\left(S_{2}\right)$ but do not elevate dopamine (D2) receptor numbers in the rat brain. Psychiatry Res 12:277-285

Leysen JE, Van Gompel P, Gommeren W, Woestenborghs $R$, Janseen PAJ (1986): Down regulation of serotonin- $S_{2}$ receptor sites in rat brain by chronic treatment with serotonin- $S_{2}$ antagonists: Ritanserin and setoperone. Psychopharmacology 88:434-444

Leysen JE, Eens A, Gommeren W, van Gompel P, Wynants J, Janssen PAJ (1987): Non-serotonergic $\left[{ }^{3} \mathrm{H}\right]$ ketanserin binding sites in striatal membranes are associated with a DOPAC release system on dopaminergic nerve endings. Eur J Pharmacol 134:373-376

Leysen JE, Eens A, Gommeren W, van Gompel P, Wynants J, Janssen PAJ (1988): Identification of nonserotonergic $\left[{ }^{3} \mathrm{H}\right]$ ketanserin binding sites associated with nerve terminals in rat brain and with platelets: relation with release of biogenic amine metabolites induced by ketanserin- and tetrabenazine-like drugs. J Pharmacol Exp Ther 244: 310-321

Lidow MS, Goldman-Rakic PS, Rakic P, Gallagher DW (1988): Differential quenching and limits of resolution in autoradiograms of brain tissue labeled with ${ }^{3} \mathrm{H}-,{ }^{125} \mathrm{I}-$ and ${ }^{14} \mathrm{C}$-compounds. Brain Res 459:105-119

Lidow MS, Goldman-Rakic PS, Gallagher DW, Rakic P (1989): Quantitative autoradiographic mapping of serotonin 5- $\mathrm{HT}_{1}$ and 5- $\mathrm{HT}_{2}$ receptors and uptake sites in the neocortex of the rhesus monkey. J Comp Neurol 280:27-42

Lowenstein PR, Joyce JN, Coyle JT, Marshall JF (1990): Striosomal organization of cholinergic and dopaminergic uptake sites and cholinergic M1 receptors in the adult human striatum: A quantitative receptor autoradiographic study. Brain Res 510:122-126

Mackay ABP, Doble A, Bird ED, Spokes EG, Ouik M, Iversen LL (1978): ${ }^{3} \mathrm{H}-S p i p e r o n e$ binding in normal and schizophrenic post-mortem human brain. Life Sci 23 : 527-532

Mann JJ, Stanley M, McBride PA, McEwen BS (1986): Increased serotonin2 and beta-adrenergic receptor binding in the frontal cortices of suicide victims. Arch Gen Psychiatry 43:954-959

McKeith IG, Marshall EG, Ferrier IN, Armstrong MM, Kennedy WN, Perry RH, Perry EK, Eccleston D (1987): 5-HT receptor binding in post-mortem brain from patients with affective disorder. J Affective Dis 13:67-74

Meltzer HY (1989): Clinical studies on the mechanism of action of clozapine: the dopamine-serotonin hypothesis of schizophrenia. Psychopharmacology 99:S18-S27

Meltzer HY, Matsubara S, Lee J-C (1989): Classification of typical and atypical antipsychotic drugs on the basis of dopamine D-1, D-2 and serotonin 2 pKi values. J Pharmacol Exp Ther 251:238-246

Mita T, Handa S, Nishino N, Kuno T, Nakai H, Yamadori T, Mizoi Y, Tanaka C (1986): Decreased serotonin $S_{2}$ and increased dopamine D2 receptors in chronic schizophrenics. Biol Psychiatry 21:1407-1414

Nieuwenhuis R, Voogd J, Van Hijzen C (1978): The Human CentralNervous System. A Synopsis and Atlas. Berlin, Springer

O'Dell SJ, La Hoste GJ, Widmark CV, Shapiro RM, Potkin SG, MarshallJF (1990): Chronic treatment with clozapine or haloperidol differentially regulates dopamine and serotonin receptors in rat brain. Synapse 6:146-153

Owen F, Cross AJ, Crow TJ, Lofthouse R, Poulter M (1981): Neurotransmitter receptors in brain in schizophrenia. Acta Psychiatr Scand 63:20-28

Pazos A, Probst A, Palacios JM (1987a): Serotonin receptors 
in the human brain. III. Auto-radiographic mapping of serotonin-1 receptors. Neuroscience 21:97-122

Pazos A, Probst A, Palacios JM (1987b): Serotonin receptors in the human brain. IV. Auto-radiographic mapping of serotonin-2 receptors. Neuroscience 21:123-139

Reynolds GP, Rossor MN, Iversen LL (1983): Preliminary studies of human cortical $5 \mathrm{HT}_{2}$ receptors and their involvement in schizophrenia and neuroleptic drug action. J Neural Transmission 18 (Suppl):273-277

Roy A (1984): Attempted suicide in chronic schizophrenia. Br J Psychiatry 144:303-306

Schotte A, Maloteaux JM, Laduron PM (1983): Characterization and regional distribution of serotonin $S_{2}$-receptors in human brain. Brain Res 276:231-235

Snedecor GW, Cochran WG (1967): Statistical Methods. Ames, Iowa, Iowa State University Press

Stanley M, Mann JJ (1983): Increased serotonin-2 binding sites in frontal cortex of suicide victims. Lancet 1:214-216

Stanley M, Virgilio J, Gushon S (1982): Tritiated imipramine binding sites are decreased in the frontal cortex of suicides. Science 18:1337-1339

Tork I (1990): Anatomy of the serotonergic system. Ann NY Acad Sci 600:9-35

Vergé D, Daval G, Marcinkiewicz M, Patey A, Mestikawy SE, Gozlan H, Hamon M (1986): Quantitative autoradiography of multiple $5-\mathrm{HT}_{1}$ receptor subtypes in the brain of control or 5,7-dihydroxytryptamine-treated rats. J Neurosci 6:3474-3482.

Vinar O, Molcan J, Nahunek K, Svestka J, Zapletalek M (1989): Ritanserin in schizophrenic patients. Activ Nerv Super 31:107-109

Whitaker PM, Crow TJ, Ferrier IN (1981): Tritiated LSD binding in frontal cortex in schizophrenia. Arch Gen Psychiatry 38:278-280

Wilmot CA, Szczepanik AM (1989): Effect of acute and chronic treatments with clozapine and haloperidol on serotonin $\left(5-\mathrm{HT}_{2}\right)$ and dopamine $\left(\mathrm{D}_{2}\right)$ receptors in the rat brain. Brain Res 487:288-298

Wilson MA, Molliver ME (1991): The organization of serotonergic projections to cerebral cortex in primates: regional distribution of axon terminals. Neuroscience 44:537-553

Winblad B, Bucht G, Gottfries CG, Roos BE (1979): Monoamines and monoamine metabolites in brains from demented schizophrenics. Acta Psychiatr Scand 60:17-28

Yates M, Leake A, Candy JM, Fairbairn AF, McKeith IG, Ferrier IN (1990): $5 \mathrm{HT}_{2}$ receptor changes in major depression. Biol Psychiatry 27:489-496

Zubenko GS, Moossy J, Martinez J, Rao G, Claassen D, Rosen J, Kopp U (1991): Neuropathologic and neurochemical correlates of psychosis in primary dementia. Arch Neurol 48:619-624 